\title{
The Strategies Used by Forced Migrants to Manage Bereavement as a Result of Multiple Losses
}

\author{
Ana M.M.S Rodrigues \\ University of Southampton, United Kingdom. ORCID: oooo-ooo3-1004-8481. \\ Email:anamargu23@hotmail.com
}

Received July 29, 2018; Revised October 02, 2018: Accepted October 27, 2018; Published October 27, 2018.

\begin{abstract}
A forced migrant is a person who tries to settle in another country after leaving their own country unwillingly, but is psychologically plagued by the past and by everything that characterises their country of origin. Therefore, there is a twofold difficulty: the forced migrant has to integrate into a country that was not desired, which causes psychological stress, while feel weakened by the losses and traumas associated with their departure.

The aim of this study was to determine what are the strategies employed by forced migrants to manage the grief experienced as a result of significant losses.

The research took the form of a systematic review of the literature, following a search on the electronic platform EBSCO host for studies published between January 2006 and January 2016. The search results were subsequently evaluated, respecting the inclusion and exclusion criteria previously established.

Seven studies met the inclusion criteria. The findings of these studies revealed that in order to manage the grief they experienced as a result of significant losses, many forced migrants used strategies based on work, socialisation, in religious observance, the continuation of their cultural practices and taking care of children.

The results suggest the need to give space to forced migrants to express their suffering, helping them to seek strategies that facilitate them in managing the grief that stems from significant losses associated with their departure from their country of origin.
\end{abstract}

Keywords: Forced migrants, loss, grief, coping strategies.

\section{1- Introduction}

Between the duality of onset of conflict in the state of origin and adaptation to the host state, a series of events emerges that may jeopardize the psychological well-being of the forced migrants. It is necessary to make a fresh start and, many times, this fresh start occurs in a country hitherto completely unknown, without mastery of the language, without documents proving academic/professional qualifications, without all family members, without the cultural references that characterized them as members of a group, with established customs full of meanings and symbolic representations (Martins-Borges, 2013).

Forced displacement involves losses and disjunctions that cannot be prepared and organised. Upon arrival in the host state, the forced migrant normally brings with him a feeling of failure, a feeling of grief at the losses incurred, as if he had had to deny his own existential continuity, many being accompanied by a feeling of nostalgia for a time they were "happy" in their state of origin (Berry, 2014). According to the same author, many forced

(C) AesthetixMS 2018. This Open Access article is published under a Creative Commons Attribution NonCommercial 4.0 International License (http://creativecommons.org/licenses/by-nc/4.o/), which permits noncommercial re-use, distribution, and reproduction in any medium, provided the original work is properly cited. For citation use the DOI. For commercial re-use, please contact editor@rupkatha.com. 
migrants are unable to envisage themselves in the host state, which in many situations is only known in the days prior to their migration. As such, the country concerned cannot be desired, imagined, as the forced migrant ends up not having the opportunity to imagine himself in the near or distant future in this new country.

Thus, as Martins-Borges (2013) claims, a forced migrant is a person who attempts to envisage himself in another country, but is mentally afflicted by a past and by everything that characterises his state of origin. As a result, here lies a twofold difficulty: the forced migrant has to integrate, as an individual, in an undesired country, a fact that obligates him to suffer psychological burden, while he feels weakened by the losses and traumas suffered. It is important to mention that, due to the nature of the conflicts that lead to the displacement of forced migrants - wars, genocides, torture, among other factors - the person carries with him an individual and collective failure, i.e. not only was he or his family affected by the conflict, but also the whole community, ethnic group or country he belongs to.

\section{2-Problem Statement}

According to Pussetti (2010), the process of forced migration constitutes a risk factor, given that it combines various losses: family and friends, language, culture, home, social position, contact with the ethnic and religious group to which he belongs. These losses are experienced as bereavement and are always accompanied by increased psychological and emotional vulnerability. As a consequence, the forced migrant has to be highly resilient, a concept, in Psychological terms, acquired through the physical sciences. However, according to Amaro (2013), resilience is not a regression to a previous state as at a physical level, but the overcoming of stressful or traumatic situations, a feature that distinguishes it from resistance insofar as resilience consists of the capacity to positively experience adversity.

Barlach (2005) states that resilience depends on the relationship that the person has with the environment in which he operates, which gives rise to his behaviour in relation to the situations and that may be adaptation or maladjustment. According to Chequini (2007, p. 94), resilience is understood as being "a process that takes into account multiple factors, a dynamic that results in the overcoming of adversity in which not only the positive adaptation of the individual is expected, but his transformation, and that of his environment". Thus, in accordance with the quoted authors, the manner in which resilience manifests itself in the case of forced migrants likewise depends on the manner in which they face adversity, specifically, losses.

Pussetti (2010, p. 96) argues that the psychological fragility of the forced migrants is not only caused by the experience of migration, but above all "their precarious socioeconomic situation, marginalization, illegality and the lack of adequate social aid: conditions that cause psychological stress". The psychological vulnerability associated with all these factors requires the support of all health care professionals, allowing the forced migrants to express their suffering, providing them with support so that they may develop coping strategies capable of providing them with culturally sensitive and competent responses. As such, the relationship between the health care professional and the forced migrant should represent a opportunity for listening to and acknowledging the other.

\section{3- Research Question}

This study seeks to possible answer to the following research question: What strategies are used by forced migrants to cope with grief in response to multiple losses? 


\section{4- Purpose of the Study}

In order to answer this question it is proposed that a careful analysis should be conducted of the existing literature relating to the grieving process of forced migrants. Thus, the objectives of the paper are as follows: i) to ascertain the difficulties experienced by the forced migrants in their grieving process; ii) to discover the strategies employed by the forced migrants to overcome their grief in relation to the losses experienced; iii) to examine how to describe the grief experienced by the forced migrants in relation to significant losses.

Systematic literature reviews allow us to identify, select and critically assess a range of studies, extracting the best scientific evidence to respond to a research question. The objective is thus to bring together all empirical evidence through the application of systematic and explicit methods, with the aim of reducing the bias that is present within existing literature (Higgins \& Green, 2011; Bettany-Saltikov, 2012). By doing so, more reliable findings are obtained from which more appropriate conclusions may be drawn and, as a consequence, important decisions regarding clinical practice may be justified.

\section{5- Research Methods}

After the first search, a first total sample of 239 papers was obtained, with the partial samples by search engines: CINAHL plus with full text; SocINDEX; ScienceDirect; MEDLINE; psycINFO Science Citation Index (via EBSCO); Delphis, Informit Humanities \& Social Sciences Collection; PubMed; and PsycARTICLES . A hand search was used after recall of all the database data.

However, given the high number of papers, it proved necessary to place limits on the search, as a result of which only the following requirements were taken into account:

1. Date of publication - January 2006 to January 2016 (initially limited between: 2011-2016 and posteriorly 2006- 2016 to ensure that pertinent articles wouldn't be missed)

2. Age $\geq 18$ years

3. Papers in the humanities

4. Papers in Portuguese and English

5. Only studies published in Europe.

With the objective of summarising the papers identified, after entering the descriptors into the EBSCO host scientific search engine, 7 articles respectively were identified.

Only studies published in Europe were reviewed, due to the multidisciplinary nature of European studies and to limit the search. However, it should be noted that these studies were conducted inside and outside the European space. Only peer reviewed studies were included to ensure credibility and, to reduce bias, grey literature was not included. A PRISMA flow diagram in Figure 1 shows the selection of papers for inclusion and exclusion.

The assessment of the quality of the studies needed to consider the use of instruments developed for this purpose, validated, and used by the scientific community. Amongst these instruments was the list of the Cochrane Back Review Group (Furlan, et al., 2009) and the critical appraisal checklist for randomised and pseudo-randomised studies of the Joanna Briggs Institute (JBI, 2011). 
Fig.1.-PRISMA

PRISMA flow diagram Adapted From: Moher D, Liberati A, Tetzlaff J, Altman DG, The PRISMA Group (2009). Preferred Reporting Items for Systematic Reviews and Meta-Analyses: The PRISMA Statement. PLoS Med 6(7): e1000097. doi:10.1371/journal.pmedioooo97

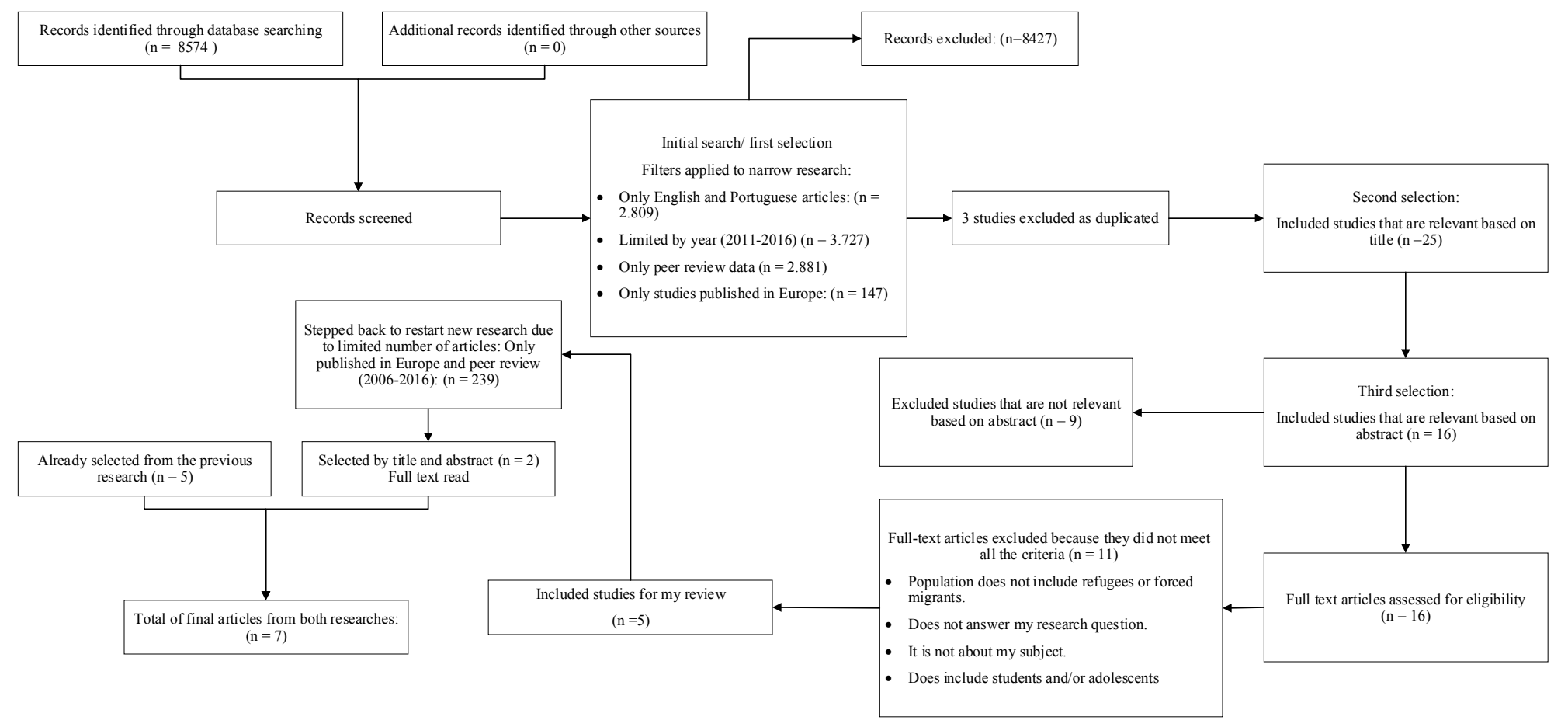


86 The Strategies Used by Forced Migrants to Manage Bereavement as a Result of Multiple Losses

\section{6- Findings}

From the papers identified through the types of search selected and the use of the methodology mentioned above, papers were selected and a critical appraisal performed, based on the selection criteria adopted. The corpus of the study consisted of seven papers.

Then, the main findings of the analysis of the selected papers are presented, which have been grouped and organised into a table to answer the research question formulated previously. Table 1 summarises the characteristics and dimensions of the papers, thus facilitating their understanding and comparison to each other, namely the method, participants/sample, objectives and main findings. A summary description is made of the most important aspects corresponding to each paper that forms part of the corpus of this systematic review. 
Table 1-Summary of the papers

\begin{tabular}{|c|c|c|c|c|c|c|c|c|c|c|}
\hline $\begin{array}{l}\text { Paper } \\
\text { number }\end{array}$ & $\begin{array}{l}\text { Paper } \\
\text { details }\end{array}$ & $\begin{array}{l}\text { Type of } \\
\text { Research }\end{array}$ & $\begin{array}{l}\text { Source } \\
\text { And } \\
\text { Database }\end{array}$ & Design & $\begin{array}{l}\text { Setting } \\
\text { of the } \\
\text { study }\end{array}$ & $\begin{array}{l}\text { Populati } \\
\text { on/ } \\
\text { Sample } \\
\text { size }\end{array}$ & Aims & Methods & $\begin{array}{l}\text { Evaluation } \\
\text { Results }\end{array}$ & $\begin{array}{l}\text { Decisio } \\
\text { n }\end{array}$ \\
\hline 1 & $\begin{array}{l}\text { African } \\
\text { Refugees } \\
\text { in Egypt: } \\
\text { Trauma, } \\
\text { Loss, and } \\
\text { cultural } \\
\text { adjustmen } \\
\text { t. } \\
\text { Henry, } \\
\text { Hani } \\
\text { M.(2012) }\end{array}$ & $\begin{array}{l}\text { Qualitative } \\
\text { Research }\end{array}$ & $\begin{array}{l}\text { Death } \\
\text { Studies } \\
\text { Medline }\end{array}$ & $\begin{array}{l}\text { Case- } \\
\text { Control } \\
\text { Studies }\end{array}$ & Egypt & $\begin{array}{l}6 \text { African } \\
\text { Refugees } \\
\text { living in } \\
\text { Egypt for } \\
\text { more } \\
\text { than } 3 \\
\text { years. }\end{array}$ & $\begin{array}{l}\text { Identify } \\
\text { the } \\
\text { Influence } \\
\text { of pre } \\
\text { immigrati } \\
\text { on trauma } \\
\text { and } \\
\text { cultural } \\
\text { losses in } \\
\text { the } \\
\text { process of } \\
\text { refugee's } \\
\text { acculturat } \\
\text { ion. }\end{array}$ & Interviews & $\begin{array}{l}\text {-Real histories of } \\
\text { adaptive and } \\
\text { maladaptive } \\
\text { bereavement; } \\
\text {-Describes coping } \\
\text { methods used by } \\
\text { refugees that } \\
\text { faced losses; } \\
\text {-Mention factors } \\
\text { that influence } \\
\text { bereavement; } \\
\text { - This sample } \\
\text { seems to be } \\
\text { fairly small. }\end{array}$ & $\begin{array}{l}\text { Include } \\
\mathrm{d}\end{array}$ \\
\hline 2 & $\begin{array}{l}\text { Posttraum } \\
\text { atic stress } \\
\text { disorder } \\
\text { and } \\
\text { prolonged } \\
\text { grief in }\end{array}$ & $\begin{array}{l}\text { Analytical } \\
\text { Cross } \\
\text { Sectional } \\
\text { Studies }\end{array}$ & $\begin{array}{l}\text { BMC } \\
\text { PsycINFO }\end{array}$ & Empirical & Sidney & $\begin{array}{l}248 \\
\text { Mandaea } \\
n \quad \text { adult } \\
\text { refugees }\end{array}$ & $\begin{array}{l}\text { Identify } \\
\text { factors } \\
\text { associated } \\
\text { with } \\
\text { symptoms } \\
\text { of refuges }\end{array}$ & Interviews & $\begin{array}{l}\text {-Methodology is } \\
\text { well defined; } \\
\text {-Talks about } \\
\text { adjustment } \\
\text { difficulties; }\end{array}$ & $\begin{array}{l}\text { Include } \\
\mathrm{d}\end{array}$ \\
\hline
\end{tabular}




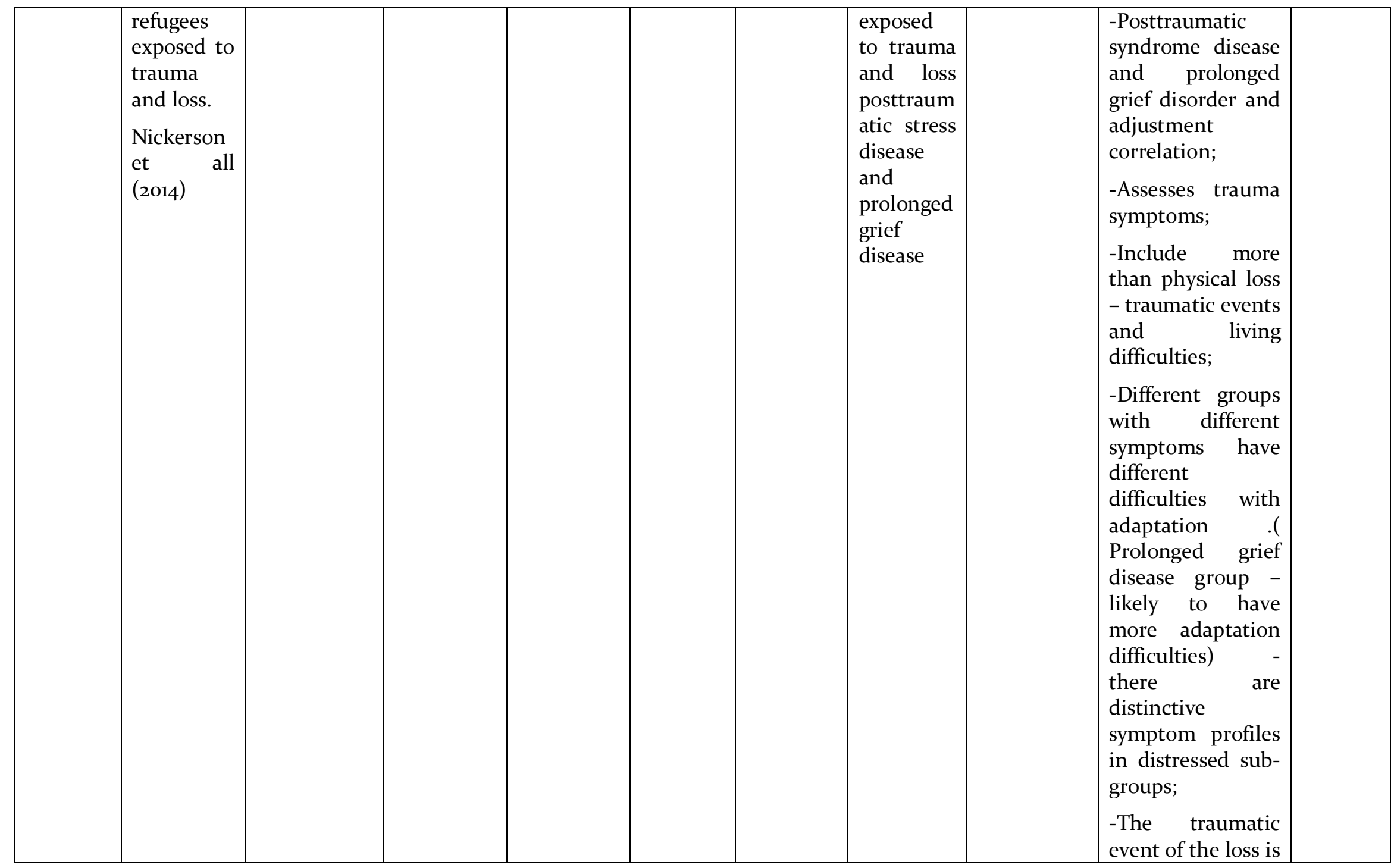


89 Rupkatha Journal on Interdisciplinary Studies in Humanities, Vol. 10, No. 3, 2018

\begin{tabular}{|c|c|c|c|c|c|c|c|c|c|c|}
\hline & & & & & & & & & $\begin{array}{l}\text { considered and } \\
\text { increases the } \\
\text { probability of } \\
\text { Posttraumatic } \\
\text { Stress Disorder/ } \\
\text { Prolonged Grief } \\
\text { Disorder } \\
\text { (PTSD/PGD) } \\
\text {-Results show that } \\
\text { that there is a } \\
\text { unique } \\
\text { relationship } \\
\text { between loss of } \\
\text { culture and } \\
\text { support and PTSD } \\
\text { reactions. }\end{array}$ & \\
\hline
\end{tabular}


90 | The Strategies Used by Forced Migrants to Manage Bereavement as a Result of Multiple Losses

\begin{tabular}{|c|c|c|c|c|c|c|c|c|c|c|}
\hline & & & & & & & & & $\begin{array}{l}\text { of identity, loss of } \\
\text { social roles, social, } \\
\text { personal and } \\
\text { cultural distress. }\end{array}$ & \\
\hline 4 & $\begin{array}{l}\text { Resource } \\
\text { loss, } \\
\text { resource } \\
\text { gain, } \\
\text { PTSD, and } \\
\text { dissociatio } \\
\text { n among } \\
\text { Ethiopian } \\
\text { immigrant } \\
\text { s in Israel. } \\
\text { Michal } \\
\text { (2016) }\end{array}$ & $\begin{array}{l}\text { Mix } \\
\text { Methods: } \\
\text { Qualitative } \\
\text { and } \\
\text { Quantitativ } \\
\text { e }\end{array}$ & $\begin{array}{l}\text { Scandinavi } \\
\text { an Journal } \\
\text { of } \\
\text { Psycholog } \\
\text { y } \\
\text { Social } \\
\text { Sciences }\end{array}$ & $\begin{array}{l}\text { Cross } \\
\text { Sectional }\end{array}$ & Israel & $\begin{array}{l}600 \\
\text { Ethiopian } \\
\text { immigran } \\
\text { ts }\end{array}$ & $\begin{array}{l}\text { Examine } \\
\text { the loss } \\
\text { and gain } \\
\text { of } \\
\text { resources, } \\
\text { posttraum } \\
\text { atic stress } \\
\text { disorder ( } \\
\text { PTSD) } \\
\text { and } \\
\text { dissociati } \\
\text { on among } \\
\text { Jewish } \\
\text { Ethiopian } \\
\text { immigran } \\
\text { ts in Israel } \\
\text { following } \\
\text { exposure } \\
\text { to } \\
\text { stressful } \\
\text { events } \\
\text { occurring } \\
\text { pre and } \\
\text { post- } \\
\text { migration }\end{array}$ & $\begin{array}{l}\text { Interviews } \\
\text { and } \\
\text { Questionna } \\
\text { ires }\end{array}$ & $\begin{array}{l}\text {-Immigrants face } \\
\text { an acculturative } \\
\text { stress due to } \\
\text { cultural loss; } \\
\text { - Loss of personal } \\
\text { resources directly } \\
\text { influence } \\
\text { acculturation } \\
\text { adaptation and } \\
\text { associated with } \\
\text { posttraumatic } \\
\text { stress disorder; } \\
\text {-Resource loss is } \\
\text { more powerful } \\
\text { than resource } \\
\text { gain; } \\
\text { - Analyses how } \\
\text { different type of } \\
\text { resources affects } \\
\text { the individual and } \\
\text { consequently the } \\
\text { process of } \\
\text { bereavement. }\end{array}$ & $\begin{array}{l}\text { Include } \\
\mathrm{d}\end{array}$ \\
\hline
\end{tabular}


91 Rupkatha Journal on Interdisciplinary Studies in Humanities, Vol. 10, No. 3, 2018

\begin{tabular}{|c|c|c|c|c|c|c|c|c|c|c|}
\hline 5 & $\begin{array}{l}\text { Mohajir } \\
\text { women } \\
\text { survivors } \\
\text { in } \\
\text { postcoloni } \\
\text { al Karachi: } \\
\text { on grief. } \\
\text { Chaudhry } \\
\text { et all } \\
(2014)\end{array}$ & Qualitative & $\begin{array}{l}\text { South } \\
\text { Asian } \\
\text { History \& } \\
\text { Culture } \\
\\
\text { Scopus }\end{array}$ & $\begin{array}{l}\text { Qualitativ } \\
\mathrm{e}\end{array}$ & Pakistan & $\begin{array}{l}58 \\
\text { Mohajir } \\
\text { women }\end{array}$ & $\begin{array}{l}\text { Analyses } \\
\text { Mohajir } \\
\text { women } \\
\text { experienc } \\
\text { es of grief }\end{array}$ & $\begin{array}{l}\text { Interviews } \\
\text { and } \\
\text { Observatio } \\
\mathrm{n}\end{array}$ & 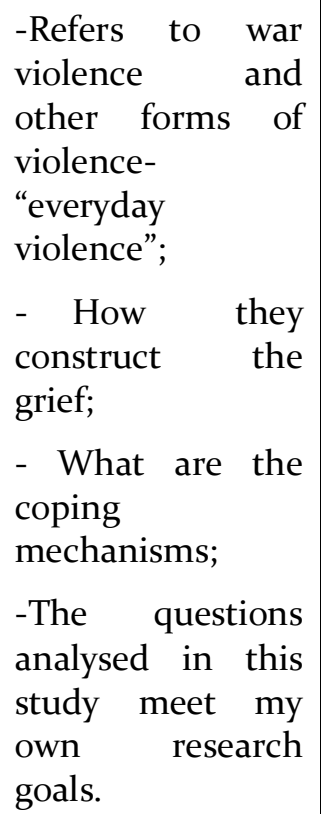 & $\begin{array}{l}\text { Include } \\
\text { d }\end{array}$ \\
\hline 6 & $\begin{array}{l}\text { Violence } \\
\text { experience } \\
\text { and } \\
\text { psycho- } \\
\text { social } \\
\text { family } \\
\text { adaptation } \\
\text { of } \\
\text { Vietnames } \\
\text { e refugee } \\
\text { women in } \\
\text { the U.S. }\end{array}$ & $\begin{array}{l}\text { Qualitative } \\
\text { Research }\end{array}$ & $\begin{array}{l}\text { Internatio } \\
\text { nal Journal } \\
\text { of } \\
\text { Psychiatric } \\
\text { Nursing } \\
\text { Research } \\
\text { CINAHL } \\
\text { Plus }\end{array}$ & $\begin{array}{l}\text { Qualitativ } \\
\mathrm{e}\end{array}$ & $\begin{array}{l}\text { United } \\
\text { States }\end{array}$ & $\begin{array}{l}30 \\
\text { Vietname } \\
\text { se } \\
\text { refugee } \\
\text { women } \\
\text { in the } \\
\text { United } \\
\text { States }\end{array}$ & $\begin{array}{l}\text { Analyses } \\
\text { disrupted } \\
\text { family ties } \\
\text { on } \\
\text { psycho- } \\
\text { social } \\
\text { family } \\
\text { adaptatio } \\
\text { n to } \\
\text { separation } \\
\text { and loss. }\end{array}$ & $\begin{array}{l}\text { Open } \\
\text { ended } \\
\text { interview } \\
\text { guide }\end{array}$ & $\begin{array}{l}\text { Ethical } \\
\text { considerations } \\
\text { were mentioned; } \\
\text { Recorded } \\
\text { interviews can } \\
\text { increase bias; }\end{array}$ & $\begin{array}{l}\text { Include } \\
\mathrm{d}\end{array}$ \\
\hline
\end{tabular}


92 The Strategies Used by Forced Migrants to Manage Bereavement as a Result of Multiple Losses

\begin{tabular}{|c|c|c|c|c|c|c|c|c|c|c|}
\hline & $\begin{array}{l}\text { Fox et all } \\
(2008)\end{array}$ & & & & & & & & & \\
\hline 7 & $\begin{array}{l}\text { Post- } \\
\text { traumatic } \\
\text { stress in } \\
\text { asylum } \\
\text { seekers } \\
\text { and } \\
\text { refugees } \\
\text { from } \\
\text { Chechnya, } \\
\text { Afghanista } \\
\text { n, and } \\
\text { West } \\
\text { Africa: } \\
\text { gender } \\
\text { differences } \\
\text { in } \\
\text { symptoma } \\
\text { tology and } \\
\text { coping. } \\
\text { Renner et } \\
\text { all (2oog) }\end{array}$ & $\begin{array}{l}\text { Mix } \\
\text { Methods: } \\
\text { Qualitative } \\
\text { and } \\
\text { Quantitativ } \\
\text { e }\end{array}$ & $\begin{array}{l}\text { Internatio } \\
\text { nal Journal } \\
\text { of Social } \\
\text { Psychiatry } \\
\text { Social } \\
\text { Sciences }\end{array}$ & $\begin{array}{l}\text { Qualitativ } \\
\mathrm{e}\end{array}$ & Austria & $\begin{array}{l}150 \\
\text { asylum } \\
\text { seekers } \\
\text { and } \\
\text { refugees } \\
\text { from } \\
\text { Chechnya } \\
\text { ' Afghanist } \\
\text { an, and } \\
\text { West } \\
\text { Africa }\end{array}$ & $\begin{array}{l}\text { Explores } \\
\text { the } \\
\text { difference } \\
\mathrm{s} \text { in } \\
\text { gender } \\
\text { concernin } \\
\mathrm{g} \text { clinical } \\
\text { symptoms } \\
\text { and } \\
\text { coping } \\
\text { strategies } \\
\text { in refuges. }\end{array}$ & $\begin{array}{l}\text { Questions } \\
\text { and } \\
\text { interviews }\end{array}$ & $\begin{array}{l}\text { Includes } \\
\text { geographic areas } \\
\text { diversity from } \\
\text { participants; } \\
\text { Analyse } \\
\text { differences } \\
\text { between gender; } \\
\text { Translation } \\
\text { resources and the } \\
\text { help- } \\
\text { participation of a } \\
\text { cultural guide } \\
\text { increase risk of } \\
\text { bias; } \\
\text { About my topic of } \\
\text { research. }\end{array}$ & $\begin{array}{l}\text { Include } \\
\text { d }\end{array}$ \\
\hline
\end{tabular}




\section{1- Linkage with native cultures}

In a qualitative study, Henry (2012) sought to discover the influence of significant losses and trauma suffered by forced migrants in their process of acculturation in the host state, as reflected in the manifestation of their links with native cultures. The sample consisted of six forced African migrants who took refuge in Egypt due to wars and political persecution, who were interviewed regarding the circumstances of their flight from their state of origin, as well as regarding their life experiences in Egypt in the process of adaptation.

The author found that all the participants continued to maintain links with their native cultures, but these links manifested themselves in a different way, depending on their ability to assimilate the traumas arising from cultural losses. The interviewees reported having successfully overcome the significant losses and cultural losses through the development of continued links with their native cultures, which helped them to integrate Egyptian culture into their life experiences and accept the difficult political conditions in Egypt in relation to forced migrants.

The continuity of their native culture contributed largely to their overcoming the traumas arising from their situation as forced migrants, these links with their native culture offering them solace.

In conclusion, these cases reflect that a successful adaptation to an unknown culture may depend on the response of the individual to the circumstances that attended their flight from their state of origin, as well as their ability to face their cultural losses.

The study also demonstrated that the impact of the trauma of the situation that leads to the condition of being a forced migrant depends on cultural beliefs, experiences and socialisation assuming themselves as strategies adopted to face the significant losses. All of the participants complained regarding the difficult political situation prevailing in Egypt, but only those who assimilated the significant losses and pre-traumatic experiences arising from the situation experienced in their state of origin were able to continue their links to their native culture, adapt to these conditions and minimise their negative influences.

\section{2- Religious belief and education}

Based on a qualitative study, Alemi et al. (2016) explored how Afghan forced migrants conceptualised their mental health, reflected in levels of depression, in relation to the trauma they experienced. Accordingly, 18 Afghanis living in the San Diego area of the USA were interviewed. Causes, symptoms and treatments in relation to the depression were studied, with narratives reporting stressful factors in relation to their integration into the community of the host state and coping mechanisms. It was demonstrated that there is a relationship between the causality of the depression and the traumas of pre-migration war, namely the separation of the family, and post-migration, including dissonance of status and cultural conflicts and linguistic differences, which generate intergenerational challenges. The depressive symptoms were seen as highly debilitating and included changes in temperament, altered cognition, evasion, dissociative behaviours and somatic complaints.

Alleviation was found via family reunification and in community support, in the faith of religious belief (prayer) and the educational success of their children in the USA. It was found that 9 forced migrants had experiences in their native country that caused depression, regardless of the sociodemographic situation, including the imprisonment of relatives, arbitrary forced entry into their home and interrogations by government agents, fear of being killed and the eminent threat of maltreatment at the hands of government factions and/or 
militias that disputed power to the point of destruction. These were the events reported that led to the participants fleeing Afghanistan for Pakistan with the help of smugglers.

The participants reported crossing mountains on foot and/or on horseback, seeking temporary shelter in villages, experiencing long periods of hunger and facing the threat of being killed along the way. These findings lead the authors to mention the need for professionals in various areas who work with forced migrants in the host country to take their significant losses and stress factors caused by cultural and linguistic impacts into account, along with the way each experiences his own struggles and devises coping strategies, so that intervention may be developed based on the needs expressed by the forced migrants.

\section{3-Support from others}

Chaudhry (2014) explored the experiences of Mohajir women and their suffering in response to losses arising during the armed conflict of 1985-1999 in Karachi, Pakistan. Probings into the suffering of the survivors and their attempts to face that suffering became starting points for understanding the impact and contours of multiple types of violence, including structural violence, of which the lives of poor women form a particular part. The memories and stories of Karachi, being threatened with death and seeing other women tortured and killed, relatives murdered and incarcerated in prisons under appalling living conditions, are implicit in their accounts of suffering, which leads them to lament losses at an individual and family level, along with the deprivation of their rights.

The violence that has permeated their lives is reflected in their current suffering. For many Mohajir women, being a forced migrant due to the whole situation experienced in their native country, where they were subject to high levels of repression and violence, represents enormous suffering. The grieving and poor Mohajir women can only find a small degree of solace among women in similar circumstances. Women aged over 50, women in the 30-40 age group and younger women demonstrate different coping mechanisms to deal with the suffering.

\section{4-Social and domestic activities}

Renner and Salem (2009) investigated the specific requirements of forced migrants from Chechnya, Afghanistan and West Africa for dealing with anxiety and post-traumatic depression through psychometric instruments that evaluate these somatic symptoms. They also studied social adaptation by means of semi-structured interviews among a sample of 150 forced migrants. They found that, in terms of total scores in the test, the women demonstrated considerably more somatic symptoms than men, but there were no other gender differences.

In respect of the categories obtained from interview data, marked differences were found in gender. In comparison to men, women reported more somatic symptoms, more acute emotional manifestations and a loss of sexual desire, while men reported detachment. In terms of total scores obtained by the psychometric measurements, men and women differed significantly only in relation to the higher frequency of somatic symptoms reported by women, while all measurements of depression, anxiety and post-traumatic stress, as well as the questionnaire on social functioning, did not result in significant gender differences.

Women reported weeping and a feeling of having a lump in their throat, as well as feeling a heaviness in their whole body more frequently than men, very often accompanied by a loss of sexual desire. For women, typical coping strategies were concentrating on their children and on various domestic activities, while men preferred to seek work and socialise. Moreover, 
in accordance with the traditional gender roles, men reported a higher degree of detachment, as well as different coping strategies, namely involvement in social activities and seeking information, where problems are generally discussed in groups.

\section{5-Culture and contextual factors}

Nickerson et al. (2014) determined whether distinct classes of post-traumatic stress disorder and psychogenic pain disorder exist in survivors of the trauma of exposure to conflicts and persecution, and examined the specific types of stressful experiences of forced migrants. The sample consists of 248 adult Mandaean forced migrants, who were assessed for an average of 4.3 years in the host state, Australia, after fleeing Iraq. The majority of the participants was male ( $48 \%)$, with an average age of 38.31 years $( \pm 14.53)$ and with an equivalent of 10.98 years of education $( \pm 3.78)$. On average, the participants had been in Australia for 4.31 years $( \pm 4.25)$. The latent class analysis revealed four classes of participants: one class combining posttraumatic stress/psychogenic pain disorder (16\%), predominantly post-traumatic stress $(25 \%)$ and a resilient class $(43 \%)$. Taking into account the fact that the class combining posttraumatic stress/psychogenic pain disorder had as predictor exposure to traumatic loss, those that exhibited greater psychogenic pain disorder showed a greater propensity to report adaptation problems since their flight from Iraq, and the individuals with greater posttraumatic stress showed a greater propensity to have difficulties relating to a loss of culture and social support.

It was demonstrated that the difference in culture and the context of the host state played a significant role in increasing the suffering of the forced migrants after the significant losses. Most of the participants described bitterness (which may be defined as feeling irritated, associated with feelings of vengeance and helplessness). This study is consistent with other research that links psychogenic pain disorder to bitterness after exposure to war (Morina, Rudari, Bleichhardt \& Prigerson, 2010). This symptom, according to the authors, may be an indicator of anguish when the loss is experienced in a violent context.

These forced migrants demonstrate difficulty in accepting the losses arising from the violent situations resulting from the conflicts experienced in the state of origin. Moreover, they experience great difficulty, in the host state, in holding acts of worship or religious rituals that represent stages of transition for overcoming/accepting their losses. This evidence demonstrates the importance of cultural and contextual factors in assessing how the forced migrants attempt to overcome the psychogenic pain arising from their losses. The study demonstrates that half the sample exhibited resilience, which is confirmed by other studies and that indicates that the majority of people exposed to trauma and significant losses recovers naturally over time and exhibit no psychopathological symptoms (Rothbaum, Foa, Riggs, Murdock \& Walsh, 1992; Bonanno, Boerner, Wortman, 2008).

Adaptation, after exposure to traumatic situations and significant losses, becomes a normative response in the context of forced migrants exposed to situations of persecution and extreme violence. Nevertheless, some forced migrants also report psychopathological symptoms as a result of their exposure to traumatic situations and significant losses, resulting in mental disorders (Mollica, McInnes, Poole \& Tor, 1998; Van Ommeren, De Jong, Sharma, Komproe, Thapa \& Cardena, 2001).

According to Neria and Litz (2004), simultaneous exposure to trauma and significant losses results in a twofold emotional charge. Thus, the combination of traumatic events and the factors related to the losses arising from them may result in symptoms relating to psychogenic pain disorder. In a study by Nickerson et al. (2014), forced migrants exposed to 
the loss of a loved one such as, for example, witnessing the murder of a loved one, experienced post-traumatic stress and psychogenic pain disorder. Thus, the authors considered that the experience of a traumatic event and simultaneously a significant loss appears to have a negative impact on the mental health of the forced migrants, resulting in a high likelihood of the onset of post-traumatic stress and psychogenic pain disorder.

According to Nickerson et al. (2014), these symptom profiles are associated with exposure to different types of experiences that the forced migrants lived through, such as traumatic significant losses.

\section{6-Employability and self esteem}

Finkelstein (2016) studied the losses and gain of resources, post-traumatic stress disorder and dissociation among Ethiopian Jewish forced migrants in Israel after exposure to stressful events, before, during and after migration. The study consisted of a random sample $(\mathrm{N}=478)$ of three waves of migrants $\left(\mathrm{N}_{1}=165 ; \mathrm{N}_{2}=169 ; \mathrm{N}_{3}=144\right)$. The data were gathered in 2001. The average age of the participants was 39.84 years $( \pm 10.14) ; 53.9 \%(n=257)$ were men and $46.1 \%$ $(\mathrm{n}=\mathbf{2 2 0})$, women. Of these participants, 165 were migrants under Operation Moses (who had been in Israel for 18 years), 169 were migrants under Operation Solomon (who had been in Israel for 10 years) and 144 were migrants under Family Reunification legislation, and had been in Israel for 6 years.

The migrants under Operation Moses had higher rates of literacy and were more religious at the time of migration than the other two groups. They arrived in Israel while still very young, predominantly single and with a low birth rate per family compared with that found in the other groups. However, among the migrants under the Family Reunification legislation, who were older when they arrived in Israel, the birth rate per family was higher compared to the other two groups. The rate of married migrants was $68 \%$ of the Operation Solomon immigrants, $78 \%$ of Family Reunification migrants and $46 \%$ of Operation Moses migrants after arrival in Israel. At the time the study was carried out, there were no difference is religiosity, the majority being religious $(46 \%)$ or traditional $(47 \%)$ and a minority, secular $(7 \%)$.

Finkelstein (2016) found significant differences in terms of the intensity of the traumatic events prior to migration: the Operation Moses migrants $(M=2.95, \pm 1.34)$ experienced more acutely traumatic events prior to migration than the Operation Solomon migrants $(M=1.98$, $\pm 1.23)$ and the Family Reunification migrants $(M=2.09, \pm 1.21)$. Likewise, significant differences were found in the difficulties experienced during the post-migration period: migrants from the Family Group $(\mathrm{M}=2.90, \pm 0.64)$ had greater difficulty in the post-migration period than the Operation Moses group $(\mathrm{M}=2.67, \pm 0.78)$ and the Operation Solomon group $(\mathrm{M}=\mathbf{2 . 5 2}, \pm 0.68)$.

The only significant difference found in the intensity of the post-traumatic stress disorder occurred between the Operation Moses migrants $(\mathrm{M}=1.78, \pm 0.63)$ and the Family Reunification migrants $(\mathrm{M}=1.74, \pm 0.59)$, who experienced it more intensely than the Operation Solomon migrants $(M=1.52, \pm 0.45)$. Nevertheless, the frequency of dissociative experiences did not differ in the migration groups.

The same study revealed that the Operation Moses migrants reported greater losses in terms of the dimension of housing than the Operation Solomon migrants and the Family Reunification Resistance. The Family Reunification migrants reported greater losses in terms of the dimension of employment than the Operation Solomon migrants. In terms of the dimension of self-esteem, Family Reunification migrants suffered greater losses than the Operation Solomon migrants. Moreover, older participants tended to report greater losses of employment and self-esteem. 
In terms of gains for coping with the losses, the most widely reported is related to housing. Younger participants managed to find more employment and gain greater self-esteem. These resources for coping with losses were acquired more by Operation Moses migrants than by Operation Solomon and Family Reunification migrants. Age did not affect the acquisition of these resources.

A significant relationship was found between the symptoms of post-traumatic stress disorder and the loss of resources for gaining self-esteem $(\mathrm{r}=0.17 ; \mathrm{p}<0.001)$, with a positive dissociation associated with gains of resources in terms of housing $(\mathrm{r}=0.20, \mathrm{p}<0.001)$. Both the post-traumatic stress disorder and the aforementioned dissociation were manifested to a greater extent by younger forced migrants. The strategies that the forced migrants found to overcome the losses and post-traumatic stress disorder consisted of seeking employability, gaining self-esteem and taking energy from their native culture.

The study performed by Finkelstein (2016) regarding losses of personal resources, such as self-esteem, and increases in psychopathological symptoms provided evidence in line with other previous studies, which demonstrate that loss of self-esteem is associated with an increase in psychopathological symptoms in forced migrants (Adams \& Boscarino, 2006; Kristen, Horsey, Palmieri \& Hobfoll, 2010), which is also consistent with the studies conducted by Renner and Salem (2009) and Nickerson et al. (2014). Finkelstein (2016) states that his findings suggest that all participants who reported a greater loss of self-esteem also reported more intense psychopathological symptoms.

Fox et al. (2008) studied Vietnamese women refugees in the United States of America, the host state, who suffered violence during the Vietnam War, taking into account their flight from Vietnam and their incarceration in concentration camps. The violent experiences included witnessing massacres, being assaulted, raped and being deprived of basic necessities in concentration camps. These women exhibited symptoms of post-migration depression, anxiety and post-traumatic stress disorder, which is also documented in the studies conducted by Renner and Salem (2009), Chaudhry (2014) and Nickerson et al. (2014), showing that forced migrants who have experienced situations of significant loss and traumatic experiences of great violence exhibit negative psychopathological and emotional responses.

In the study conducted by Fox et al. (2008), one of the greatest traumas experienced by the Vietnamese women was separation from their families, both in Vietnam and in the USA. The standard consequences of the breaking of family ties among forced migrants are psychopathological symptoms, which require a further adaptation to current life in the state of origin. In the study conducted by Fox et al. (2009), employment constituted a new psychosocial family adaptation for the Vietnamese women, given that none of them worked in Vietnam. Moreover, the women reported that staying at home all day alone was boring and caused them even more suffering due to their grieving for the family members from whom they had been separated. In these cases, work served not only to provide a better standard of living, but also as a distraction from their emotional pain.

Although it was clear that most of the women were not very satisfied with the work they had in the USA (factory work, cleaning, cooking and laundry services), there were other perceived benefits, i.e. the women reported their personal satisfaction as a result of the employment, for example being more exposed to North American culture, an opportunity to study the English language and socialization, these being strategies for coping with the situations of loss. 


\section{7-Conclusion}

From the articles analysed, despite the fact that the vast majority of the forced migrants have been exposed to traumatic situations of significant loss prior to travelling to the host state and during their adaptation to that country, with a culture, language and socio-political structure different from that of the state of origin, the studies identify that they develop psychopathological symptoms related to grief and trauma. Forced abandonment of their state of origin is always a stressful situation associated with the psychogenic pain disorder arising from their losses.

It was found that in work, in socialisation, in religious worship, in the continuation of their cultural practices and in the attention paid to their children, many forced migrants find strategies for managing the grief that they experience in relation to their significant losses.

It was clear that the need should be recognised for their involvement in integration initiatives in the host state, this being an effective means for living a dignified life where genuine respect is shown for human rights.

It is necessary to create more support centres for forced migrants staffed by professionals from various areas of knowledge, such as nurses, who should be open to listening, dialogue and respect for the rights of these people, under a holistic approach.

Accordingly, it is believed that this systematic review of the literature has reinforced even further the assumption that greater efforts must be made to intervene in relation to mental health among traumatized forced migrants, which should include not only the treatment of post-traumatic psychopathological symptoms, but also ensure that those people can gain resources such as self-esteem and a deeper understanding of their anguish, which may result in a gain in other resources for them to be able to manage their grief in relation to their significant losses.

As a nurse, in my professional practice with forced migrants, I consider it important to know how to listen to a person's individual story, helping him to alleviate the pain arising from his traumatic experiences, whether in his state of origin or in the host state.

It is not easy for a forced migrant to articulate with certainty what his intentions are for the future. Very often, part of his response is beyond his control. Very often, the current precariousness of their lives leads them to suffer an increase in major psychological suffering. Thus, the residential establishment should be considered as the only solution for the recovery of lost freedom and dignity, which implies turning it into a safe haven where these people who have experienced truly traumatic situations in their state of origin are treated with dignity.

It can be seen that, by its very nature, mental health is one of the most delicate aspects of the problem of forced migrants, due to their situation of vulnerability and due to the need to acquire cultural competencies, whether at the personal and professional level or even at the institutional and organizational level of the state of origin. This vulnerability may lead the forced migrants to appeal for help, and it is in this context that all psychological support should be provided, taking into account the experiences of each individual. Opportunity should be given for them to express their suffering, and they should be helped to find strategies that facilitate the management of their grief over their significant losses.

In short, services geared to populations of forced migrants should provide an opportunity for listening to and acknowledging others. 


\section{References}

Adams, R.E. \& Boscarino, J.A. (2006). Predictors of PTSD and delayed PTSD after disaster: The impact of exposure and psychosocial resources. Journal of Nervous and Mental Disease, 194, 485-493.

Alemi, Q., James, S., \& Montgomery, S. (2016). Contextualizing Afghan refugee views of depression through narratives of trauma, resettlement stress, and coping. Transcultural Psychiatry, Vol. 53(5): 630-653.

Alemi, Q., Stempel, C., Baek, B., Lares, L., Villa,, P., Danis, D., \& Montgomery, S. (2016). Impact of Postmigration Living Difficulties on the Mental Health of Afghan Migrants Residing in Istanbul. International Journal of Population Research Volume 2016 (2016), Article ID 7690697, 8 pages

Amaro, L.S. (2013). Resiliência em pacientes com câncer de mama: o sentido da vida como mecanismo de proteção. Revista da Associação Brasileira de Logoterapia e Análise Existencial, 2(2), 147-161.

Barlach, L. (2005). O que é resiliência humana? Uma contribuição para a construção do conceito. São Paulo: Instituto de Psicologia.

Berry, J.W. (2014). Migração, aculturação e adaptação. In de Biaggi, S., \& Paiva, G.J.de (orgs.).Psicologia, E/Imigração e Cultura (pp. 29-45). São Paulo: Casa do Psicólogo.

Bettany-Saltikov, J. (2012). How to Do a Systematic Literature Review in Nursing: A Step-By-Step Guide. Nova Iorque: Open University Press. ISBN-13: 9780335242276.

Bonanno, G.A., Boerner, K., Wortman, C.B. (2008). Trajectories of grieving. In Handbook of bereavement research and practice: Advances in theory and intervention. Edited by Stroebe MS, Hansson RO, Schut H, Stroebe W. Washington DC: American Psychological Association; 287307.

Chaudhry, L.N. (2014). Mohajir women survivors in postcolonial Karachi: on grief. Jounal South Asian History and Culture, Volume 5, Issue 3

Chequini, M.C.M. (2007). A relevância da espiritualidade no processo de resiliência.

Revista de Psicologia, Vol. 16, 1/2, 93-117.

Finkelstein, M. (2016). Resource loss, resource gain, PTSD, and dissociation among Ethiopian immigrants in Israel. Scandinavian Journal of Psychology, 57, 328-337.

Fox, P.G., Baldwin, K.B., Rossetti, J., Plonczynski, D. et al. (20o8). Violence experience and psycho-social family adaptation of vietnamese refugee women in the U.S.

Furlan, A., Tomlinson, G., Furlan, A. D., Pennick, V., Bombardier, C., \& van Tulder, M. (n.d). 2009 Updated Method Guidelines for Systematic Reviews in the Cochrane Back Review Group. Spine, 34(18), 1929-1941.

Henry, H.M. (2012). African Refugees in Egypt: Trauma, Loss, and Cultural Adjustment. Death Studies, v. 36, 7, 583-604.

Higgins J., \& Green S. (2011). Cochrane Handbook for Systematic Reviews of Interventions Version 5.1.0. The Cochrane Collaboration.

The Joanna Briggs Institute. (2011). Joanna Briggs Institute Reviewers' Manual. University of Adelaide. Retrieved May 4, 20017, from http://joannabriggs.org/assets/docs/sumari/ReviewersManual2011.pdf

Kristen, H.W., Horsey, K.J., Palmieri, P.A. \& Hobfoll, S.E. (2010). The role of protective self-cognitions in the relationship between childhood trauma and later resource loss. Journal of Trauma and Stress, 23, 264-273

Martins-Borges, L. (2013). Migração involuntária como fator de risco à saúde mental. 
Rev. Inter. Mob. Hum., Brasília, Ano XXI, 40, 151-162.

Michal, H. (2016). Resource loss, resource gain, PTSD, and dissociation among Ethiopian immigrants in Israel.

Moher D, Liberati A, Tetzlaff J, Altman DG, The PRISMA Group (2009). Preferred Reporting Items for Systematic Reviews and Meta-Analyses: The PRISMA Statement. PLoS Med 6(7): e1000097. doi:10.1371/journal.pmedioooo97

Mollica, R.F., McInnes, K., Poole, C., Tor, S. (1998). Dose-effect relationships of trauma to symptoms of depression and post-traumatic stress disorder among Cambodian survivors of mass violence. $\mathrm{BrJ}$ Psychiatry, 173: 482-488.

Morina, N., Rudari, V., Bleichhardt, G.,. Prigerson, H.G. (2010). Prolonged grief disorder, depression, and posttraumatic stress disorder among bereaved Kosovar civilian war survivors: a preliminary investigation. Int J Soc Psychiatry, 56(3): 288-297.

Neria, Y., Litz, B.T.(2004). Bereavement by traumatic means: the complex synergy of trauma and grief. $J$ Loss Trauma, 9: 73-88.

Nickerson, A., Liddell, B.J., Maccallum, F, Steel, Z., Silove, D. \& Bryant, R.A. (2014). Posttraumatic stress disorder and prolonged grief in refugees exposed to trauma and loss. BMC Psychiatry, 14,106, 2-11

Pussetti, C. (2010). Identities in Crisis: migrants, emotions and mental health in Portugal. Saúde Soc.

São Paulo, v.19, 1, 94-113.

Renner, w. \& Salem, I. (2009). Post-traumatic stress in asylum seekers and refugees from Chechnya, Afghanistan, and west Africa: gender differences in symptomatology and coping. International Journal of Social Psychiatry; Vol 55(2): 99-108. DOI: 10.1177/0020764008092341

Rothbaum, B.O., Foa, E.B., Riggs, D.S., Murdock, T., Walsh, W. (1992). A prospective examination of post-traumatic stress disorder in rape victims. J Trauma Stress, 5(3):455-475.

Van Ommeren, M., De Jong, J.T., Sharma, B., Komproe, I., Thapa, S.B., Cardena, E. (2001) Psychiatric disorders among tortured Bhutanese refugees in Nepal. Arch Gen Psychiat, 58: 475-482 


\section{8- Appendix}

The JBI Critical Appraisal Checklist for the qualitative research

\begin{tabular}{|c|c|c|c|c|c|}
\hline Papers & $\begin{array}{l}\text { Renner et all (2009) } \\
\text { Post-traumatic of } \\
\text { asylum seekers and } \\
\text { refugees from } \\
\text { Chechnya, } \\
\text { Afghanistan and } \\
\text { Western Africa: } \\
\text { gender differences } \\
\text { in symptomatology } \\
\text { and coping", } \\
\text { International } \\
\text { Journal of Social } \\
\text { Psychiatry, 55, 2, p. } \\
99-108 \text {. }\end{array}$ & $\begin{array}{l}\text { Fox et all (2008) } \\
\text { The experience of } \\
\text { violence and } \\
\text { psychosocial } \\
\text { support the } \\
\text { adaptation of the } \\
\text { family } \\
\text { Vietnamese } \\
\text { refugee women in } \\
\text { the } \\
\text { U.S, International } \\
\text { Journal of Research } \\
\text { In Psychiatric } \\
\text { Nursing, 14 1679- } \\
1697,1, p \text {. }\end{array}$ & $\begin{array}{l}\text { Henry, H.M. } \\
(2012) \text {. African } \\
\text { refugees in Egypt: } \\
\text { Trauma, loss and } \\
\text { cultural } \\
\text { adaptation. Studies } \\
\text { of Death, v. 36, } 7 \text {, p. } \\
583-604 .\end{array}$ & $\begin{array}{l}\text { Alemi, P., Stempel, } \\
\text { C., Baek, B., Homes, } \\
\text { L., Villa, P., Danis, } \\
\text { D., } \\
\text { \& Lucas, S. (2016), } \\
\text { Impact of the } \\
\text { difficulties of Life } \\
\text { Postmigration on the } \\
\text { mental health of } \\
\text { migrants resident } \\
\text { Afghans Inter in } \\
\text { Istanbul. Internation } \\
\text { al Journal of } \\
\text { Research Population } \\
\text { 2o16 Volume (2016), } \\
\text { Article ID 7690697, } 8 \\
\text { pages }\end{array}$ & $\begin{array}{l}\text { Chaudhry, L.N. } \\
(2014) \text { Mohajir } \\
\text { surviving } \\
\text { women in } \\
\text { Karachi: post- } \\
\text { colonial about } \\
\text { the r pain. } \\
\text { Journal of } \\
\text { history and } \\
\text { culture of } \\
\text { South Asia, } \\
\text { Volume 5, Issue } \\
3\end{array}$ \\
\hline
\end{tabular}




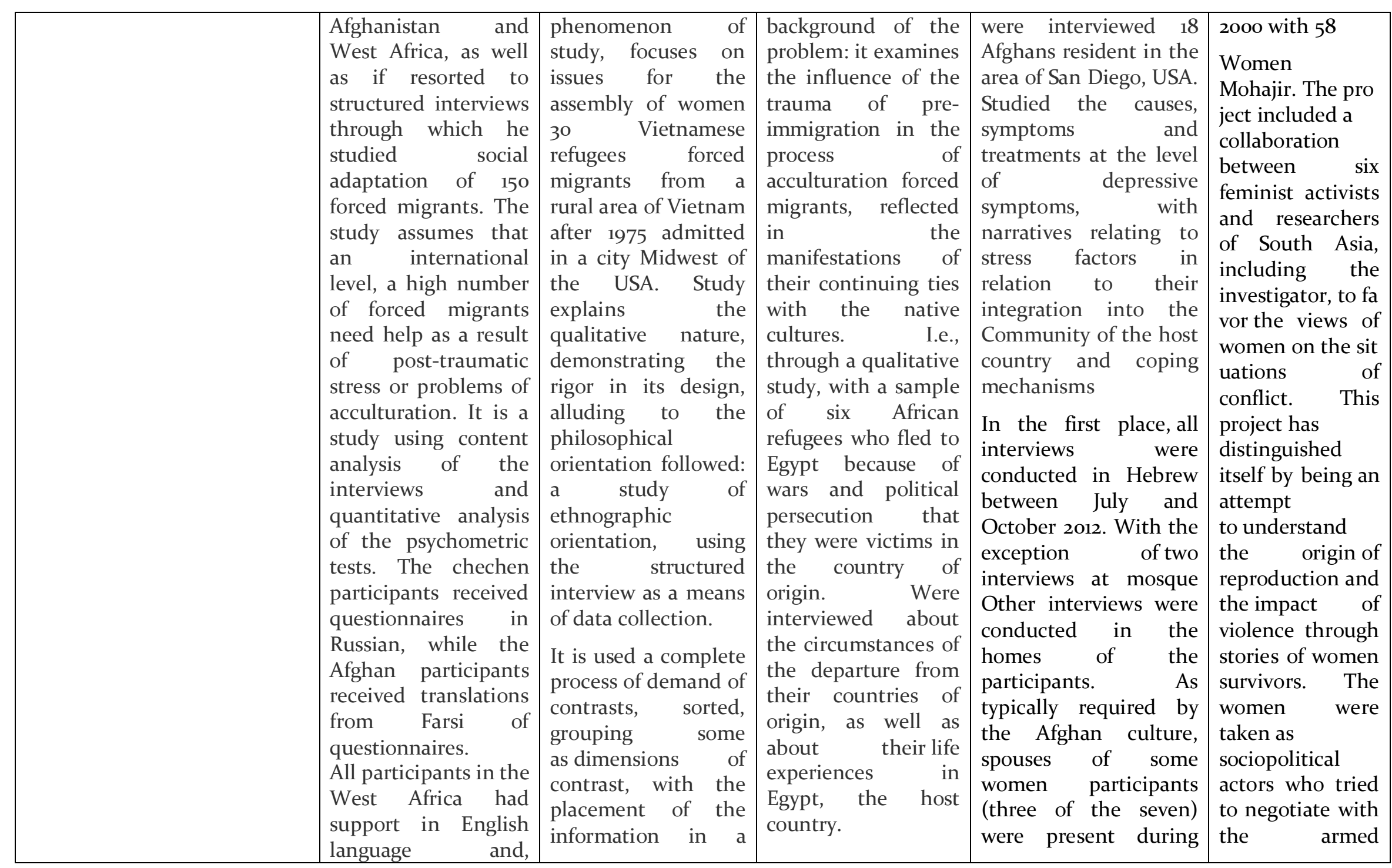




\begin{tabular}{|c|c|c|c|c|c|}
\hline & $\begin{array}{l}\text { therefore, the } \\
\text { psychometric } \\
\text { questionnaires were } \\
\text { administered in its } \\
\text { original form (HSCL- } \\
\text { 25, HTQ, IES-R, BSI } \\
\text { and SASS - Form } \\
\text { answered so on paper } \\
\text { registration); the } \\
\text { CAPS-1 was } \\
\text { conducted as a } \\
\text { structured interview } \\
\text { with the help of } \\
\text { interpreters based in } \\
\text { its German version } \\
\text { with participants } \\
\text { from Chechnya and } \\
\text { Afghanistan, while } \\
\text { the English version } \\
\text { was used for the } \\
\text { interviews with } \\
\text { participants from } \\
\text { West Africa. }\end{array}$ & paradigm. & & $\begin{array}{l}\text { the interviews. The } \\
\text { interviews } \\
\text { between } 45 \text { minutes } \\
\text { and an hour. } \\
\text { Recording } \\
\text { Applications }\end{array}$ & $\begin{array}{l}\text { violence and } \\
\text { structural } \\
\text { violence to } \\
\text { ensure their own } \\
\text { survival and their } \\
\text { families in } \\
\text { a world distorted } \\
\text { by conflict }\end{array}$ \\
\hline $\begin{array}{l}\text { 2.There is congruity } \\
\text { between the research } \\
\text { methodology and the } \\
\text { research problem or goals? }\end{array}$ & $\begin{array}{l}\text { Yes. The study } \\
\text { consists af } \\
\text { quantitative and } \\
\text { qualitative methods, } \\
\text { questionnaires and } \\
\text { structured interviews } \\
\text { were applied, }\end{array}$ & $\begin{array}{l}\text { Yes } \\
\text { A qualitative study } \\
\text { was made using } \\
\text { semi-structured } \\
\text { interviews. This } \\
\text { method was selected }\end{array}$ & $\begin{array}{l}\text { Yes. The study } \\
\text { methodology is } \\
\text { congruent with the } \\
\text { research problem. } \\
\text { Observations were } \\
\text { used to refine and } \\
\text { modify the template: }\end{array}$ & $\begin{array}{l}\text { Yes. The study } \\
\text { methodology is } \\
\text { adequate to deal with } \\
\text { the issue of research. } \\
\text { The qualitative } \\
\text { methodology followed } \\
\text { took into account that }\end{array}$ & $\begin{array}{l}\text { Yes. There is } \\
\text { congruence } \\
\text { between the } \\
\text { methodology } \\
\text { and the problem } \\
\text { and consequent } \\
\text { goals, being a }\end{array}$ \\
\hline
\end{tabular}




\begin{tabular}{|c|c|c|c|c|c|}
\hline & $\begin{array}{l}\text { respectively. The } \\
\text { study methodology is } \\
\text { adequate to deal with } \\
\text { the issue of research. } \\
\text { Psychometric } \\
\text { instruments were } \\
\text { used to analyze and } \\
\text { cooping } \\
\text { Symptomatology and } \\
\text { researchers used } \\
\text { methods of data } \\
\text { collection in the } \\
\text { context of the culture } \\
\text { in the present study, } \\
\text { such as structured } \\
\text { interviews } \\
\text { (population: total of } \\
\text { 15o refugees and } \\
\text { asylum seekers in } \\
\text { Austria of Chechnya, } \\
\text { Afghanistan and } \\
\text { Western Africa:) - } \\
\text { ethnographic and } \\
\text { approach phenomenological } \\
\text { perspective and } \\
\text { quantitative analysis. }\end{array}$ & $\begin{array}{l}\text { as the most } \\
\text { appropriate means to } \\
\text { obtain detailed data } \\
\text { and rich on the } \\
\text { prospects of the } \\
\text { Vietnamese refugee } \\
\text { women on family } \\
\text { adaptation. There is } \\
\text { congruence between } \\
\text { the qualitative } \\
\text { methodology, the } \\
\text { research problem } \\
\text { and objectives. The } \\
\text { woman who served } \\
\text { as a guide was } \\
\text { Vietnamese, social } \\
\text { worker on a } \\
\text { voluntary in the } \\
\text { organization in the } \\
\text { community. The } \\
\text { option is due to the } \\
\text { fact that it is very } \\
\text { well known and } \\
\text { respected in the } \\
\text { community and } \\
\text { spoke fluent English } \\
\text { and Vietnamese, } \\
\text { managing to provide } \\
\text { the acceptability } \\
\text { necessary for } \\
\text { researchers to } \\
\text { interview the women } \\
\text { in the community. }\end{array}$ & $\begin{array}{l}\text { growing theory. It is } \\
\text { a detailed study of } \\
\text { multiple cases for } \\
\text { the drafting of a } \\
\text { report of continuous } \\
\text { bonds of forced } \\
\text { migrants Africans } \\
\text { with the native } \\
\text { culture (Egyptian), } \\
\text { so that } \\
\text { distinguishing } \\
\text { features, as well as } \\
\text { the common } \\
\text { characteristics, such } \\
\text { as those related to } \\
\text { the contextual } \\
\text { factors, could } \\
\text { usefully inform the } \\
\text { growing theory. }\end{array}$ & $\begin{array}{l}\text { the forced migrants } \\
\text { Afghans are a difficult } \\
\text { group to access. } \\
\text { Perhaps in relation to } \\
\text { the potential stigma to } \\
\text { participate in a study of } \\
\text { mental health, this } \\
\text { required the } \\
\text { identification of } \\
\text { culturally sensitive } \\
\text { methods to gain the } \\
\text { confidence of the } \\
\text { participants, i.e., to } \\
\text { have access to } \\
\text { the community } \\
\text { of forced af } \\
\text { migrants afghans as a } \\
\text { preliminary step in the } \\
\text { research process. So, } \\
\text { before a } \\
\text { commencing their stud } \\
\text { y, the authors } \\
\text { conducted preliminary } \\
\text { interviews with key } \\
\text { informants with leaders } \\
\text { of the clergy } \\
\text { and the Afghan } \\
\text { community and with health } \\
\text { professionals } \\
\text { and professionals } \\
\text { related to resettlement } \\
\text { in Afghanistan and not }\end{array}$ & $\begin{array}{l}\text { continuity of } \\
\text { a job } \\
\text { Previously } \\
\text { performed based } \\
\text { on data set, this } \\
\text { time using the } \\
\text { words of women } \\
\text { to focus } \\
\text { explicitly on the } \\
\text { loss, sadness and } \\
\text { grief experienced } \\
\text {. In addition to } \\
\text { other } \\
\text { deprivations, } \\
\text { such as } \\
\text { The loss of } \\
\text { livelihoods and } \\
\text { the home, most } \\
\text { of } \\
\text { the participants } \mathrm{f} \\
\text { aced the violent } \\
\text { death of a male } \\
\text { member of the } \\
\text { family. }\end{array}$ \\
\hline
\end{tabular}




\begin{tabular}{|c|c|c|c|c|c|}
\hline & & 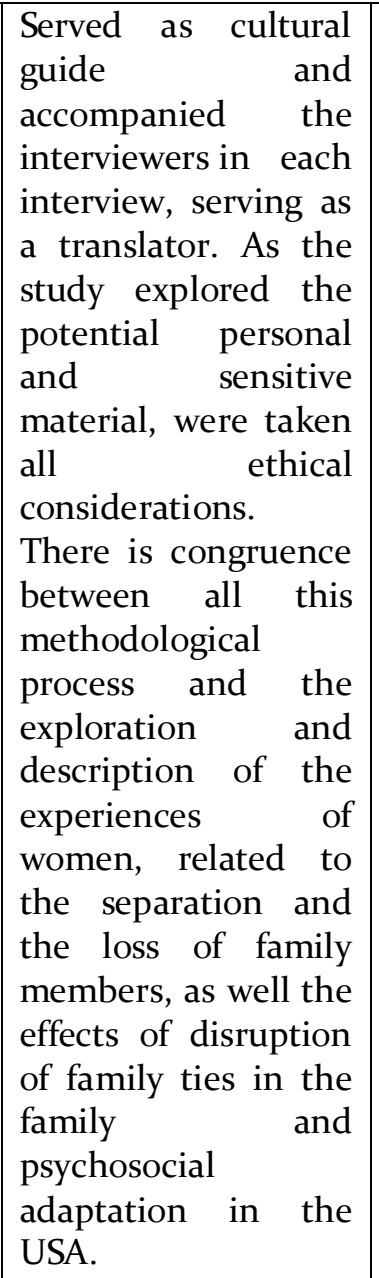 & & $\begin{array}{l}\text { in Afghanistan, as well } \\
\text { as focus groups with } \\
\text { community members } \\
\text { of various ages. Topics } \\
\text { included: 1) The size of } \\
\text { the population of } \\
\text { forced } \\
\text { migrants Afghans and } \\
\text { the sociodemographic } \\
\text { composition in the San } \\
\text { Diego area; } \\
\text { suggestions } \\
\text { on effective strategies } \\
\text { for sampling, } \\
\text { recruitment, and assess } \\
\text { the receptivity of the } \\
\text { Afghans to } \\
\text { participate in a study of } \\
\text { "mental health"; and } \\
\text { 3) the stressors and } \\
\text { mental health } \\
\text { conditions that affect } \\
\text { the forced } \\
\text { migrants Afghans. }\end{array}$ & \\
\hline congruity & Data & study & Yes. The & There & There \\
\hline
\end{tabular}




\begin{tabular}{|c|c|c|c|c|c|}
\hline $\begin{array}{l}\text { between the research } \\
\text { methodology and data } \\
\text { collection methods? }\end{array}$ & $\begin{array}{l}\text { collected through } \\
\text { two questionnaires } \\
\text { and structured } \\
\text { interviews. }\end{array}$ & $\begin{array}{l}\text { followed a } \\
\text { phenomenological } \\
\text { approach and data } \\
\text { were collected } \\
\text { through } \\
\text { phenomenological } \\
\text { interviews. Data } \\
\text { were collected } \\
\text { through a basic } \\
\text { script, with audio } \\
\text { recording, giving } \\
\text { special attention to } \\
\text { the thoughts and } \\
\text { sentiments expressed } \\
\text { by women. The } \\
\text { recording helped a } \\
\text { lot in data analysis } \\
\text { and ensured the } \\
\text { quality of results. }\end{array}$ & $\begin{array}{l}\text { followed a } \\
\text { phenomenological } \\
\text { approach and the } \\
\text { data were collected } \\
\text { through } \\
\text { phenomenological } \\
\text { interviews, aiming to } \\
\text { obtain rich } \\
\text { descriptions of the } \\
\text { experiences of } \\
\text { each interviewee, } \\
\text { without following } \\
\text { rigidly standardized } \\
\text { questions. Appeal } \\
\text { also to the } \\
\text { observation of the } \\
\text { contextual } \\
\text { environment of each } \\
\text { participant. }\end{array}$ & $\begin{array}{l}\text { congruence between } \\
\text { the methodology } \\
\text { and data collection. }\end{array}$ & $\begin{array}{l}\text { congruence } \\
\text { between the } \\
\text { methodology } \\
\text { and data } \\
\text { collection. }\end{array}$ \\
\hline $\begin{array}{l}\text { 4. There is congruity } \\
\text { between the research } \\
\text { methodology and the } \\
\text { representation and analysis } \\
\text { of data? }\end{array}$ & $\begin{array}{l}\text { Yes. The meanings } \\
\text { of all participants are } \\
\text { included in the } \\
\text { study. The authors } \\
\text { describe the } \\
\text { differences between } \\
\text { the sexes in terms of } \\
\text { symptoms } \\
\text { and coping strategies. }\end{array}$ & $\begin{array}{l}\text { Yes The study } \\
\text { followed a } \\
\text { phenomenological } \\
\text { approach to exploit } \\
\text { the experience of } \\
\text { women in relation to } \\
\text { separation and the } \\
\text { loss of family } \\
\text { members, as well the } \\
\text { effects of disruption } \\
\text { of family ties in the } \\
\text { family and } \\
\text { psychosocial }\end{array}$ & $\begin{array}{l}\text { Yes. The data were } \\
\text { analyzed and } \\
\text { represented as } \\
\text { congruent with the } \\
\text { methodological } \\
\text { position, with } \\
\text { exploration of the } \\
\text { influence of } \\
\text { significant losses } \\
\text { and trauma of forced } \\
\text { migrants in their } \\
\text { process of } \\
\text { acculturation in the }\end{array}$ & $\begin{array}{l}\text { Yes. The data are } \\
\text { analysed and } \\
\text { represented in } \\
\text { way that } \\
\text { is consistent with the } \\
\text { methodological } \\
\text { position. As a result, it } \\
\text { has avoided transcripts } \\
\text { verbal responses; thus, } \\
\text { the copious notes were } \\
\text { taken by the first } \\
\text { author during and } \\
\text { immediately after }\end{array}$ & Unclear \\
\hline
\end{tabular}




\begin{tabular}{|c|c|c|c|c|c|}
\hline & & $\begin{array}{l}\text { adaptation in the } \\
\text { USA. Thus, } \\
\text { participants were } \\
\text { asked to describe } \\
\text { their experiences of } \\
\text { significant losses, as } \\
\text { well as experiments, } \\
\text { taken as violent, } \\
\text { which included } \\
\text { witnessing } \\
\text { massacres, being } \\
\text { attacked, raped and } \\
\text { the deprivation of } \\
\text { basic necessities of } \\
\text { life in concentration } \\
\text { camps. Reporting } \\
\text { also its adaptation to } \\
\text { the host country. }\end{array}$ & $\begin{array}{l}\text { host country, } \\
\text { reflected in the } \\
\text { manifestations of } \\
\text { their ties with the } \\
\text { native cultures. }\end{array}$ & 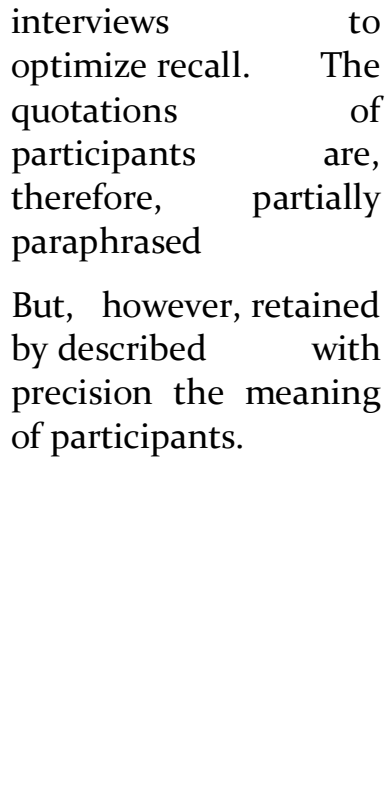 & \\
\hline
\end{tabular}




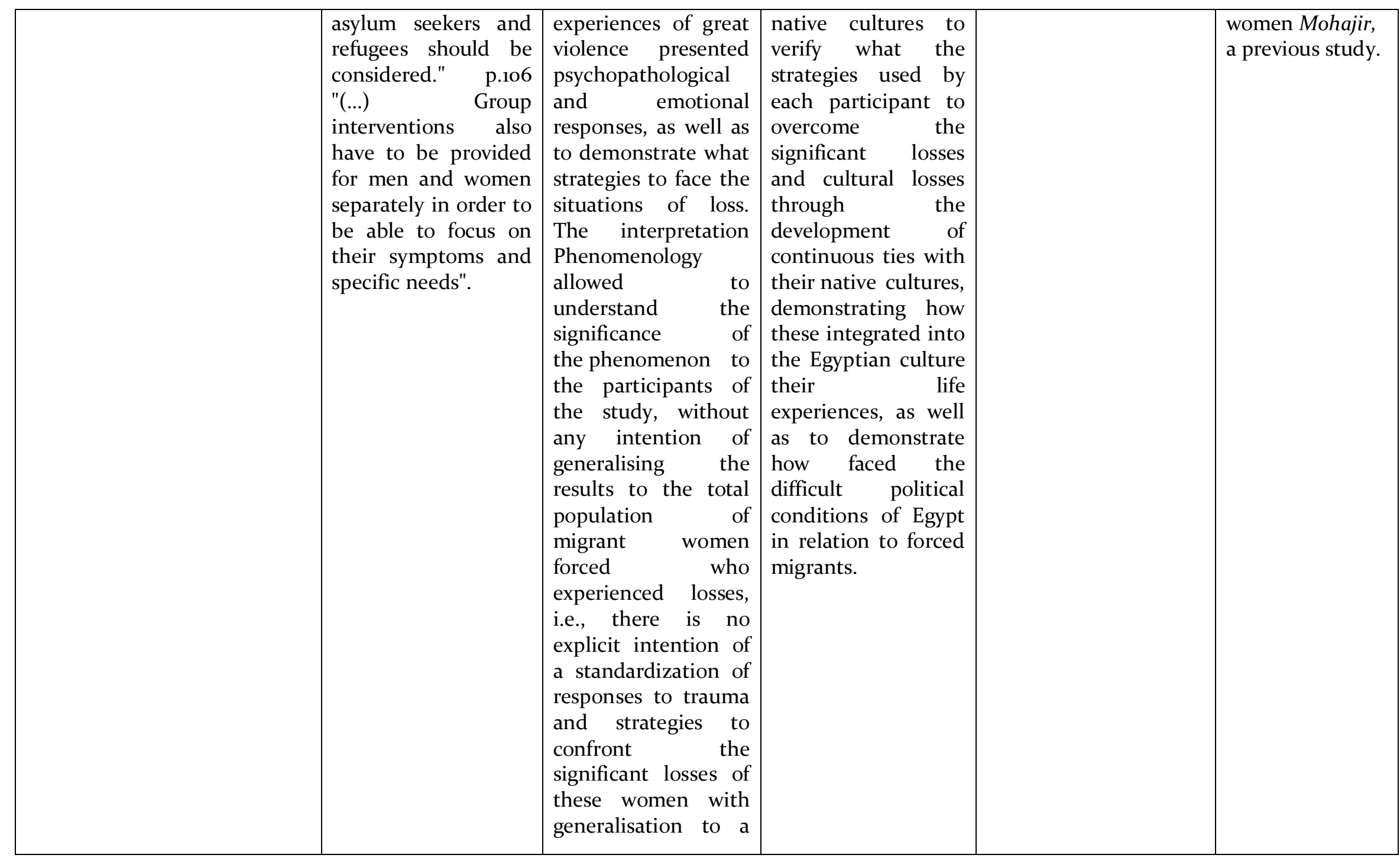




\begin{tabular}{|c|c|c|c|c|c|}
\hline & & wider population. & & & \\
\hline $\begin{array}{l}\text { 6.There is a statement by } \\
\text { locating the researcher } \\
\text { culturally or theoretically? }\end{array}$ & $\begin{array}{l}\text { Yes. The researchers } \\
\text { play an important } \\
\text { role in the process of } \\
\text { qualitative research, } \\
\text { with demonstration } \\
\text { of its importance in } \\
\text { the assessment of the } \\
\text { evidence. There is a } \\
\text { cultural recognition } \\
\text { and theoretical } \\
\text { orientation as } \\
\text { support of the results } \\
\text { obtained. }\end{array}$ & $\begin{array}{l}\text { Yes. The authors } \\
\text { reveal know the } \\
\text { universe researched } \\
\text { culturally, providing } \\
\text { theoretical } \\
\text { orientation on the } \\
\text { subject, i.e., make a } \\
\text { theoretical } \\
\text { contextualisation of } \\
\text { the repercussions of } \\
\text { the Vietnam war on } \\
\text { women forced } \\
\text { migrants who have } \\
\text { migrated to the } \\
\text { United States. Is } \\
\text { done a framework on } \\
\text { the memories of } \\
\text { experiences of } \\
\text { violence during the } \\
\text { war, his escape from } \\
\text { Vietnam and in } \\
\text { concentration ar are } \\
\text { camps. } \\
\text { addressed the } \\
\text { psychological and } \\
\text { social implications of } \\
\text { the loss and the }\end{array}$ & $\begin{array}{l}\text { Yes. The investigator } \\
\text { has an important } \\
\text { role in the process of } \\
\text { qualitative research, } \\
\text { giving signs of } \\
\text { theoretical } \\
\text { orientation. Reveals } \\
\text { knowledge about the } \\
\text { phenomenon under } \\
\text { study, alluding to } \\
\text { the cultural } \\
\text { adjustment of forced } \\
\text { migrants Africans, } \\
\text { having developed } \\
\text { and refined the use } \\
\text { of continuous bonds } \\
\text { model of mourning } \\
\text { in the understanding } \\
\text { of acculturation, } \\
\text { examining the role } \\
\text { of contextual } \\
\text { influences on the } \\
\text { outcome of this } \\
\text { process. The study } \\
\text { examines in the } \\
\text { influence of the } \\
\text { trauma of pre- }\end{array}$ & $\begin{array}{l}\text { Yes. The authors reveal } \\
\text { know the universe } \\
\text { researched culturally, } \\
\text { providing theoretical } \\
\text { orientation on the } \\
\text { subject. Even the first } \\
\text { preconceived notions } \\
\text { of the author and the } \\
\text { possible concepts that } \\
\text { were based on the } \\
\text { experiences of forced } \\
\text { migrants afghans were } \\
\text { revised in theory } \\
\text { concepts } \\
\text { about beliefs about dep } \\
\text { ression and other } \\
\text { mental health } \\
\text { problems, to sustain } \\
\text { empirically the results. }\end{array}$ & Unclear. \\
\hline
\end{tabular}




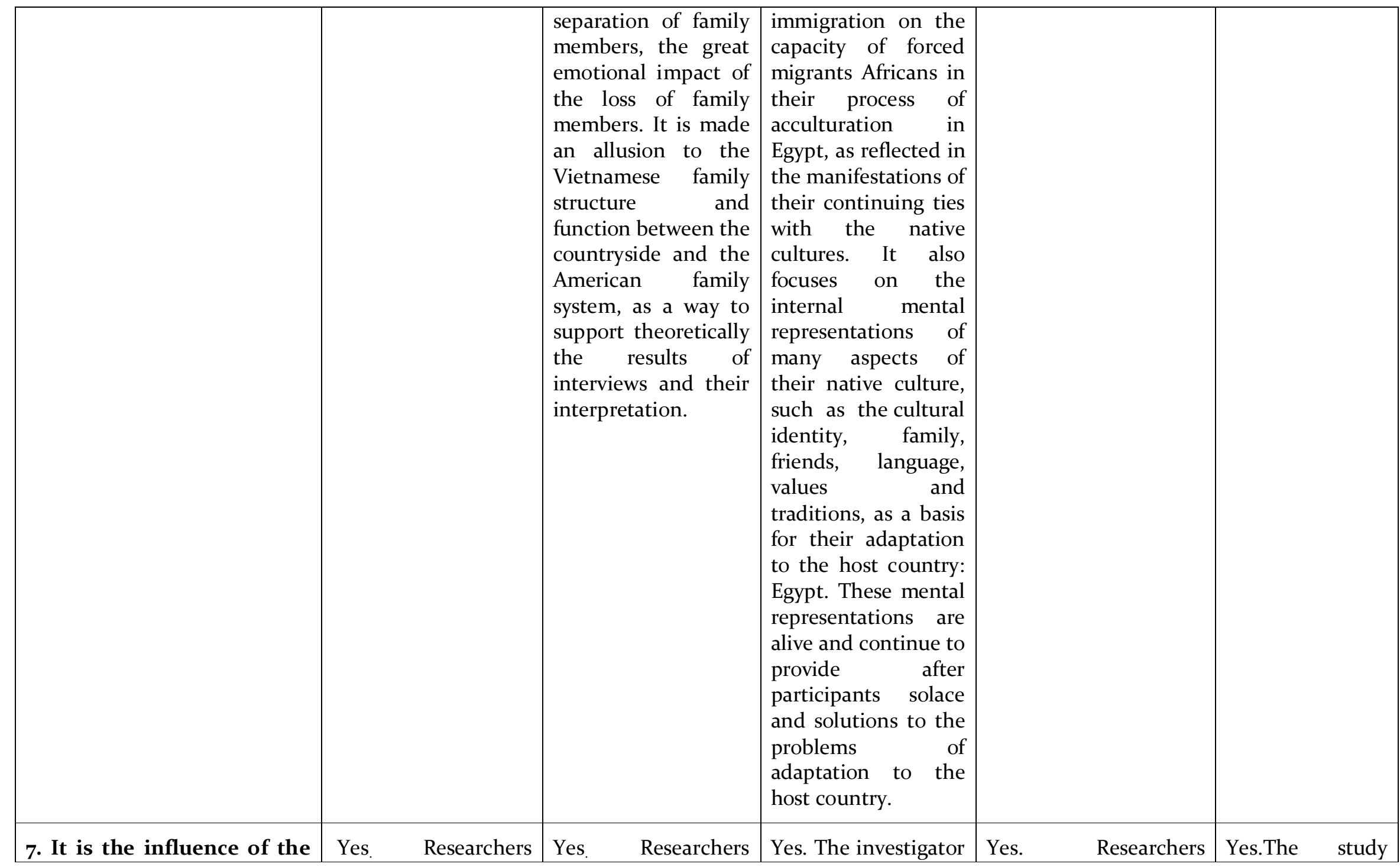




\begin{tabular}{|c|c|c|c|c|c|}
\hline $\begin{array}{l}\text { researcher on the research, } \\
\text { and vice-versa, directed? }\end{array}$ & $\begin{array}{lr}\text { examine } & \text { critically } \\
\text { their own } & \text { role and } \\
\text { potential } & \text { influence } \\
\text { during } & \text { data } \\
\text { collection. } & \end{array}$ & $\begin{array}{l}\text { examine critically } \\
\text { their own role and } \\
\text { potential influence } \\
\text { during data } \\
\text { collection, having as } \\
\text { a guide a Vietnamese } \\
\text { woman known by } \\
\text { the Community of } \\
\text { the interviewees. } \\
\text { While explicit its } \\
\text { role of interviewers. }\end{array}$ & $\begin{array}{l}\text { critically examines } \\
\text { its own role and } \\
\text { potential influence } \\
\text { during the data } \\
\text { collection, reporting } \\
\text { as responded to the } \\
\text { events that occurred } \\
\text { during the study. }\end{array}$ & $\begin{array}{l}\text { examine critically their } \\
\text { own role and potential } \\
\text { influence during data } \\
\text { collection. }\end{array}$ & $\begin{array}{l}\text { included a } \\
\text { collaboration } \\
\text { between six } \\
\text { feminist activists } \\
\text { and researchers } \\
\text { of South Asia, } \\
\text { including the } \\
\text { investigator. }\end{array}$ \\
\hline $\begin{array}{l}\text { 8. Are participants, and } \\
\text { their voices, adequately } \\
\text { represented? }\end{array}$ & 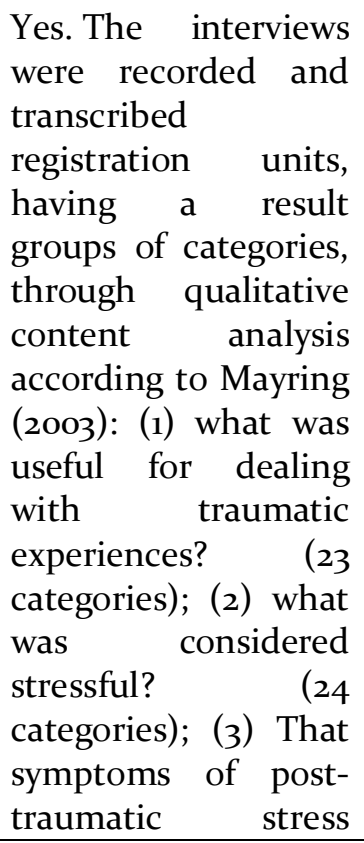 & $\begin{array}{l}\text { Yes. It provides } \\
\text { illustrations of data } \\
\text { to demonstrate the } \\
\text { basis of conclusions } \\
\text { and to ensure that } \\
\text { the participants are } \\
\text { submitted } \\
\text { anonymously, by } \\
\text { following the ethical } \\
\text { precepts of a } \\
\text { qualitative study. }\end{array}$ & $\begin{array}{l}\text { Yes. The study } \\
\text { provides illustrations } \\
\text { of results to show } \\
\text { the basis of its } \\
\text { conclusions and to } \\
\text { ensure that the } \\
\text { participants are } \\
\text { represented in the } \\
\text { same, demonstrating } \\
\text { that the complaints } \\
\text { of all participants on } \\
\text { the difficult political } \\
\text { conditions in Egypt. } \\
\text { prevailing in } \\
\text { There is a } \\
\text { demonstration that } \\
\text { only those who } \\
\text { assimilated their } \\
\text { significant losses }\end{array}$ & $\begin{array}{l}\text { Yes. They were heard } \\
\text { and recorded the } \\
\text { testimonies of } 18 \\
\text { Afghans, } 11 \text { men and } \\
\text { seven women aged } \\
\text { between } 36 \text { and } 71 \\
\text { years old, } \\
\text { predominantly } \\
\text { pashtun ethnic. }\end{array}$ & $\begin{array}{l}\text { Yes.The } \\
\text { testimonies of } \\
\text { the Mohajir, } \\
\text { women are well } \\
\text { represented, with } \\
\text { explicit their past } \\
\text { experience and } \\
\text { present, as well } \\
\text { as the different } \\
\text { coping } \\
\text { mechanisms } \\
\text { against } \\
\text { suffering. }\end{array}$ \\
\hline
\end{tabular}




\begin{tabular}{|c|c|c|c|c|c|}
\hline & $\begin{array}{l}\text { attributable to PTSD } \\
\text { (15 categories) or } \\
\text { concepts specifically } \\
\text { cultural ( } 24 \\
\text { categories) have been } \\
\text { tested? And (4) What } \\
\text { are the traumatic } \\
\text { events remembered? } \\
\text { ( } 6 \text { categories). Thus, } \\
\text { we obtained a total of } \\
92 \text { categories that } \\
\text { emerged from the } \\
\text { transcripts of } 150 \\
\text { interviews. }\end{array}$ & & $\begin{array}{l}\text { and the pre- } \\
\text { traumatic } \\
\text { experiences resulting } \\
\text { from the conditions } \\
\text { experienced in their } \\
\text { country of origin is } \\
\text { that they were able } \\
\text { to give continuity to } \\
\text { its bonds native } \\
\text { culture to adapt to } \\
\text { these conditions and } \\
\text { minimize their } \\
\text { negative influences. }\end{array}$ & & \\
\hline $\begin{array}{l}\text { 9. It is the ethics of } \\
\text { research, in accordance } \\
\text { with the current criteria, or } \\
\text { by recent studies, and there } \\
\text { is evidence of ethics } \\
\text { approval by an appropriate } \\
\text { body? }\end{array}$ & $\begin{array}{l}\text { Yes. For the } \\
\text { recording of } \\
\text { structured interviews } \\
\text { was prompted the } \\
\text { informed consent, } \\
\text { respecting the } \\
\text { confidentiality of } \\
\text { data. }\end{array}$ & $\begin{array}{l}\text { Yes. It was requested } \\
\text { permission of every } \\
\text { woman to record the } \\
\text { interview, having all } \\
\text { participated } \\
\text { voluntarily, i.e., } \\
\text { there is the } \\
\text { assumption of an } \\
\text { informed consent. } \\
\text { The recording of the } \\
\text { interviews focused } \\
\text { on the thoughts and } \\
\text { sentiments expressed } \\
\text { by women. }\end{array}$ & $\begin{array}{l}\text { Yes. The participants } \\
\text { responded to a } \\
\text { booklet of study } \\
\text { published in the } \\
\text { old campus of the } \\
\text { American University } \\
\text { in Cairo and in the } \\
\text { offices of the } \\
\text { UNHCR also in } \\
\text { Egypt. Were } \\
\text { safeguarded the } \\
\text { rights and the } \\
\text { guarantee of security } \\
\text { of the interviewees, } \\
\text { for protection of } \\
\text { their identity, not to } \\
\text { feel more vulnerable } \\
\text { and marginalised in }\end{array}$ & $\begin{array}{l}\text { Yes. Were followed } \\
\text { all ethical precepts, } \\
\text { having participants } \\
\text { refused the audio } \\
\text { recording of the } \\
\text { interview. } \\
\text { This study was } \\
\text { reviewed and } \\
\text { approved } \\
\text { by the Institutio } \\
\text { nal University } \\
\text { Branch } \\
\text { The Review Board } \\
\text { (IRB). } \\
\text { techniques were used } \\
\text { to maximum variation } \\
\text { to represent a wide }\end{array}$ & $\begin{array}{l}\text { Yes. There is no } \\
\text { reference to the } \\
\text { true identity of } \\
\text { women. The } \\
\text { study assumes to } \\
\text { safeguard the } \\
\text { confidentiality of } \\
\text { participants, } \\
\text { these being only } \\
\text { the knowledge of } \\
\text { the research } \\
\text { team. }\end{array}$ \\
\hline
\end{tabular}




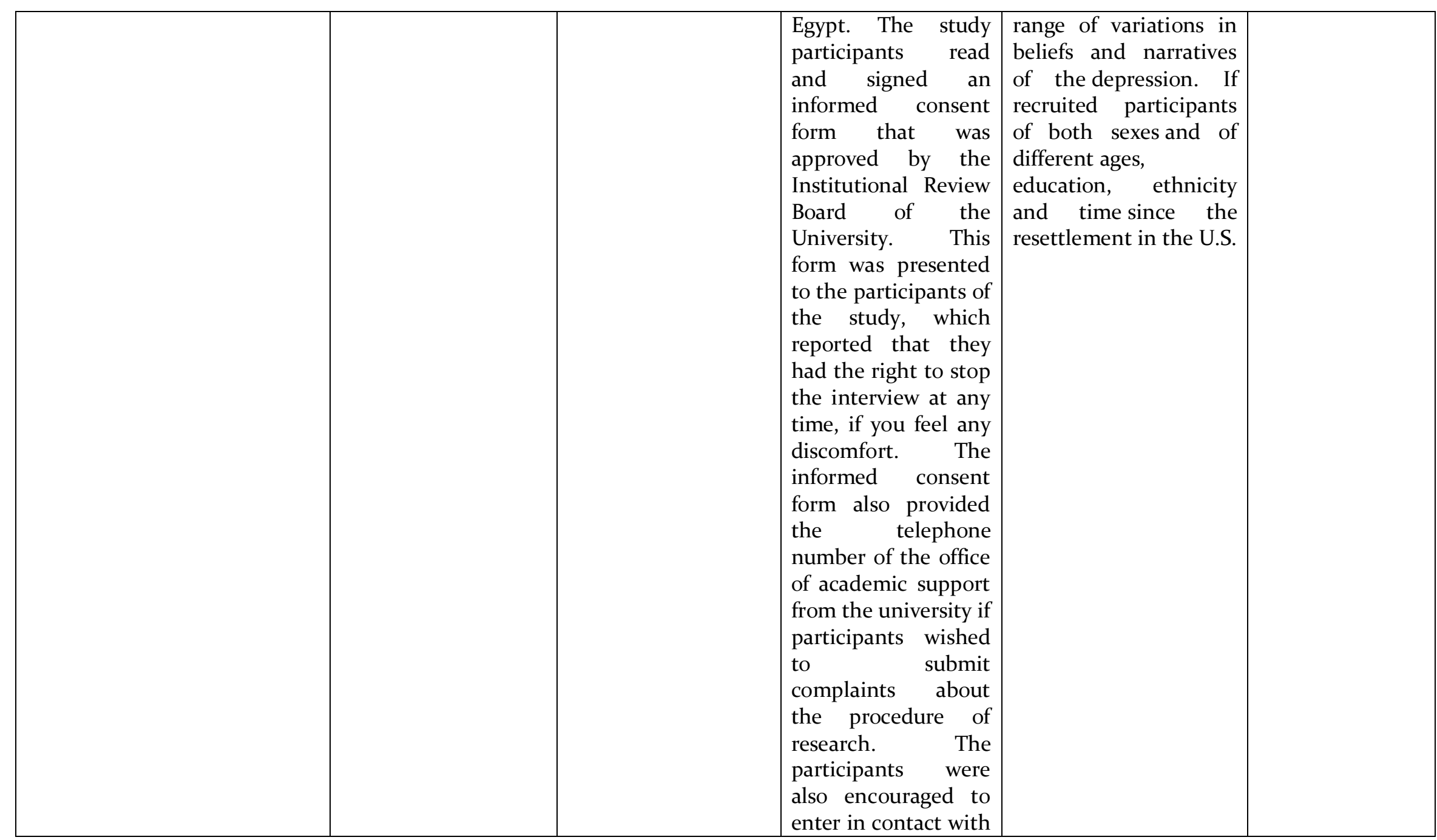




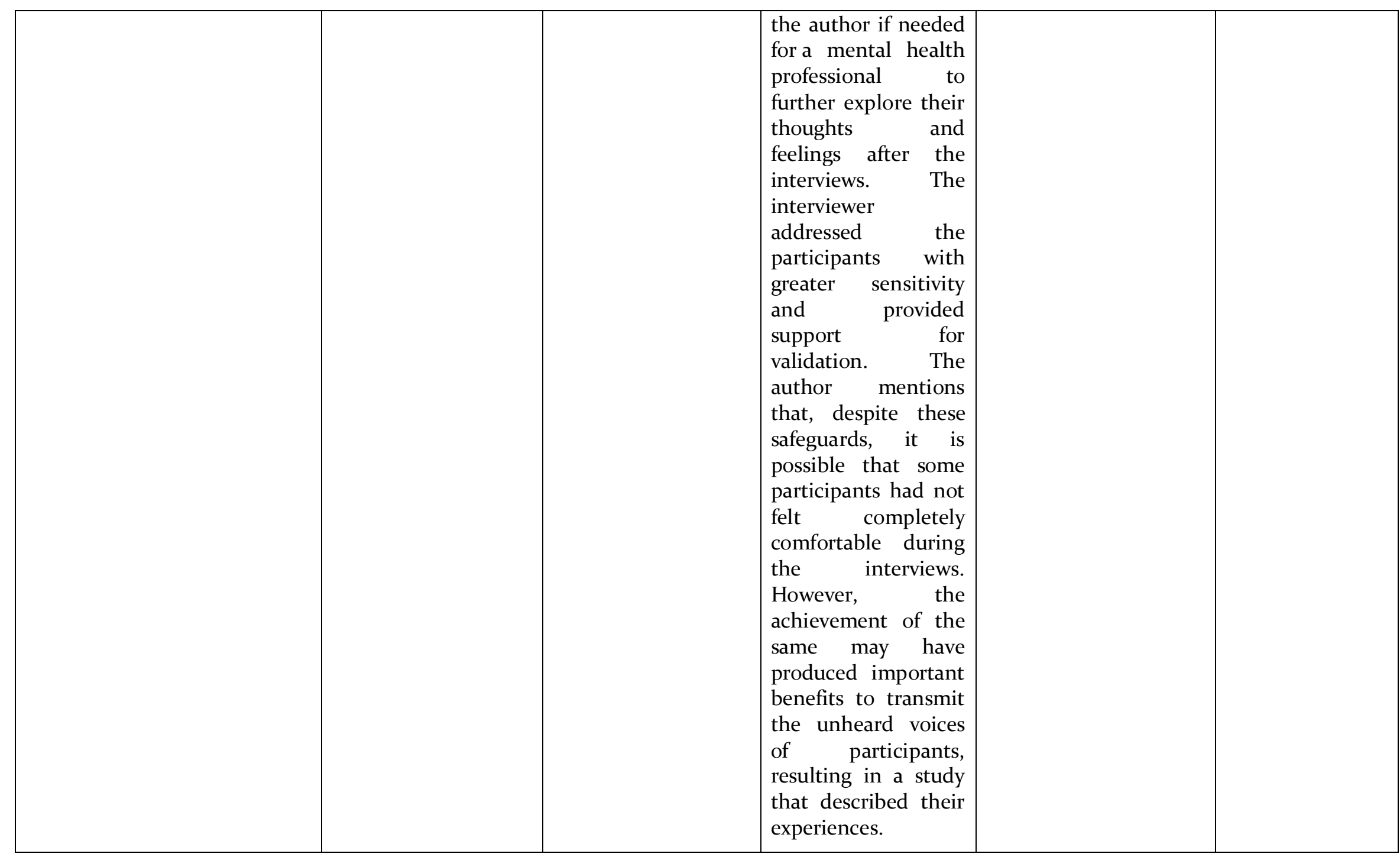




\begin{tabular}{|c|c|c|c|c|c|}
\hline $\begin{array}{l}\text { 10. Do the conclusions } \\
\text { drawn in the survey report } \\
\text { from the analysis of flow, or } \\
\text { interpretation, data? }\end{array}$ & $\begin{array}{l}\text { Yes. The research } \\
\text { findings are based on } \\
\text { data collected, taking } \\
\text { as a basis the } \\
\text { hypothesis that } \\
\text { gender specific } \\
\text { results could be } \\
\text { obtained by: (1) } \\
\text { quantitative } \\
\text { measures of post- } \\
\text { traumatic symptoms } \\
\text { and somatic effects, } \\
\text { as well as a } \\
\text { questionnaire of } \\
\text { social adaptation; } \\
\text { and (2) By structured } \\
\text { interviews in order } \\
\text { qualitative, in develop } \\
\text { to recommendations for } \\
\text { the psychiatric social } \\
\text { assistance given to } \\
\text { differential needs of } \\
\text { men and women } \\
\text { participating in the } \\
\text { study. }\end{array}$ & $\begin{array}{l}\text { Yes. There is a } \\
\text { relation between the } \\
\text { results and the } \\
\text { visions and the } \\
\text { words of the } \\
\text { participants of the } \\
\text { study. The } \\
\text { researchers shall } \\
\text { ensure that the } \\
\text { research findings are } \\
\text { based on data } \\
\text { collected; and } \\
\text { discussion of the } \\
\text { results from the text } \\
\text { generated through } \\
\text { interviews, with } \\
\text { triangulation with } \\
\text { authors who } \\
\text { represent these } \\
\text { reports. }\end{array}$ & $\begin{array}{l}\text { Yes. The conclusions } \\
\text { from the analysis of } \\
\text { the results are } \\
\text { presented taking } \\
\text { into account also the } \\
\text { theoretical } \\
\text { foundations of } \\
\text { models built. The } \\
\text { investigator reveals } \\
\text { to have ensured that } \\
\text { the findings of their } \\
\text { research are based } \\
\text { on data collected by } \\
\text { means of interviews } \\
\text { with forced migrants } \\
\text { Africans, who were } \\
\text { in Egypt. }\end{array}$ & $\begin{array}{l}\text { Yes. The conclusions } \\
\text { from the analysis of the } \\
\text { results are presented, } \\
\text { taking into account } \\
\text { also the theoretical } \\
\text { foundations of models } \\
\text { built. }\end{array}$ & $\begin{array}{l}\text { Yes. The } \\
\text { article document } \\
\text { s an analysis of } \\
\text { interviews with } \\
\text { women Mohajir } \\
\text { survivors of } \\
\text { Karachi post- } \\
\text { colonial to taking } \\
\text { into account: the } \\
\text { violence and } \\
\text { sorrow; the } \\
\text { management of } \\
\text { grief; and 'raise } \\
\text { the dead'. } \\
\text { Reveals how } \\
\text { these } \\
\text { women were } \\
\text { tormented by } \\
\text { memories of arm } \\
\text { ed conflict and } \\
\text { subsequent } \\
\text { situation of } \\
\text { forced migrants. }\end{array}$ \\
\hline The decision & $\begin{array}{l}\text { Included. According } \\
\text { to the critical }\end{array}$ & $\begin{array}{l}\text { Included. According } \\
\text { to the critical }\end{array}$ & $\begin{array}{l}\text { Included. According } \\
\text { to the critical }\end{array}$ & $\begin{array}{l}\text { Included. } \\
\text { According to the }\end{array}$ & $\begin{array}{l}\text { Included. } \\
\text { According to the }\end{array}$ \\
\hline
\end{tabular}




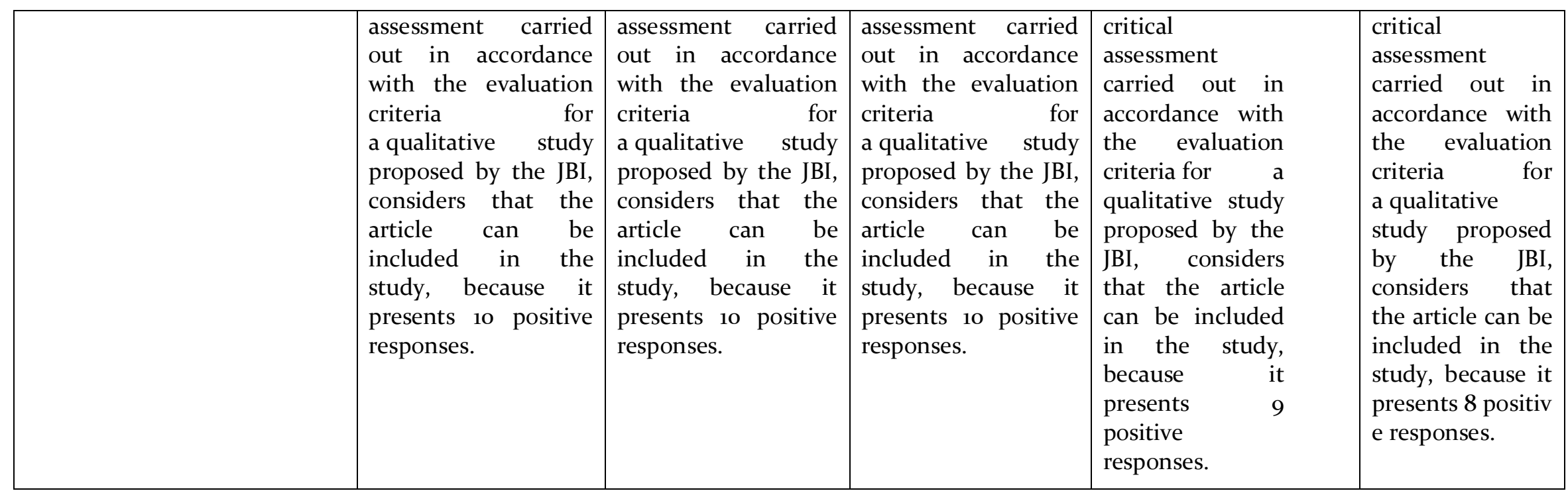

\section{The JBI checklist of critical evaluation analytics to cross-sectional studies}

\begin{tabular}{|l|l|}
\hline & $\begin{array}{l}\text { Finkelstein, M. (2016). Resource loss, resource gain, PTSD, and dissociation among Ethiopian } \\
\text { immigrants in Israel. }\end{array}$ \\
\hline $\begin{array}{l}\text { Were the criteria for inclusion in the } \\
\text { sample clearly defined }\end{array}$ & $\begin{array}{l}\text { Yes. Sampling of aleatory type for convenience. Type of cluster sampling in a total of 6oo Ethiopian } \\
\text { immigrants, withdrawal of 14 different urban municipalities to obtain a similar number of } \\
\text { immigrants and each one of the three waves of migration. }\end{array}$ \\
\hline $\begin{array}{l}\text { Were the subjects of study and the } \\
\text { configuration described in detail? }\end{array}$ & $\begin{array}{l}\text { Yes. Contact information with participants was removed from the Ministry of the Interior, using } \\
\text { age stratification in a random sample (for example, 30-36, 37-43, 44-50), with an equal number of } \\
\text { men and to obtain a representative sample. The sample size was determined using a power value of } \\
\text { o.8o and type I error of o.o5. As the group differences were unknown, an effect size of o.13 was } \\
\text { determined to detect differences between the groups. Thus, a sample of } 576 \text { reached the power }\end{array}$ \\
\hline
\end{tabular}


level and the size of the sample target was defined as 600 in total, 200 individuals per group.

The exposure was measured in a valid and reliable?

rater

Yes. The study clearly describes the method for measuring exposure. This is the reliability of the processes included in the study, with the reliability intra-rater and inter-rater reliability.

The questionnaires were administered by the research assistants: male assistants for the male population and female assistants for the female population. The majority of the questionnaires $(n=417 ; 87 \%)$ was administered orally; $13 \%(n=61)$ were self-administered.

\section{Were objectives, default criteria used for the measurement of the state?}

Were identified as factors of confusion?

Were strategies to deal with confounding factors stated?

The outcomes were measured in a valid and reliable?
Unclear

Unclear

Yes. The stratification of the sample, with adjustments, to evaluate the statistics used in the study. It was performed a multivariate regression analysis to take account of the factors measured.

Yes. The group differences of traumatic events, traumatic peri-migration and post-migration difficulties were evaluated by analysis of variance (ANOVA). We used the Chi-squared to assess the prevalence of those who met the criteria for PTSD, by wave of immigration. It was used the Pearson correlation between PTSD, dissociation of gains and losses of resources, taking into account the age. We used the t-test to examine differences in PTSD, taking into account the gender, marital status and the academic qualifications. Multivariate analyses were used to

Variance (MANOVA) to evaluate differences in loss and gain of resources by wave of immigration. Multiple regressions were conducted to examine the prediction of PTSD and decoupling for gain and loss of resources, age, wave of immigration and exposure to traumatic events peri and postmigration.

The statistical analysis used was Yes. Descriptive analysis was used and the inferential statistics. 
118 | The Strategies Used by Forced Migrants to Manage Bereavement as a Result of Multiple Losses

\begin{tabular}{|l|l|}
\hline adequate? & \\
\hline The decision & $\begin{array}{l}\text { In accordance with the criteria analysed, and taking into account that Article } 6 \text { received positive } \\
\text { responses and } 2 \text { unclear, included in the literature review. }\end{array}$ \\
\hline
\end{tabular}


Admissions, A., Liddell, B.J., Maccallum, F, Steel, Z. Silove, D., \& Bryant, J. (2014). Post-traumatic stress disorder and prolonged sadness in refugees exposed to trauma and loss. 14,106 BMC Psychiatry, p. 2-11

1. Were the criteria for inclusion in the sample clearly defined?

Yes. The study included a specific group: refugees exposed to traun
years from the entry of Portugal as a result of persecution in Iraq.

2. Were the subjects of study and the configuration described in detail?

3. The exposure was measured
in a valid and reliable?

Resident in Sydney, Australia, who reported that they

Yes
Yes. Sample clearly identified: "Participants were 248 adults of the Mandaean community

He had lost a loved one."p.2; (...) "who were evaluated, on average, 4.3 years from the entry of Portugal.

The data were collected between September 2006 and November 2007.

There is a clear description of demography, location and time period.

Gives details of exposure of a population in time and space as transcribed above. Determines how the majority of the population to be selected

There is a clear relationship between the measure and the phenomenon under study

Provide a basis for comparisons of culture.

Is the amount of time and effort are needed for the respondents to devote to the interviews; and affirms that there were incentives for the participants.

After the nature of

The study was explained, the informed consent was obtained 


\begin{tabular}{|c|c|}
\hline & For all participants, and the study was approved by Ethics. \\
\hline $\begin{array}{l}\text { 4. Objective, standard criteria } \\
\text { were used for the measurement } \\
\text { of the state? }\end{array}$ & $\begin{array}{l}\text { Yes } \\
\text { This study investigating symptom profiles } \\
\text { The Pos traumatic and prolonged suffering among refugees resettled } \\
\text { Kill exposed to trauma and loss. } \\
\text { Diagnostic methods are used, such as: The Harvard Trauma questionnaire was used to } \\
\text { Evaluate exposure to trauma and pos traumatic symptoms and the Inventory of Symptoms of complicated grief, } \\
\text { measurement of PGD and the subscale of Checklist-Depression Symptom Hopkins } \\
\text { [19] was used to measure depression symptoms } \\
\text { Main characteristics are present, for example: "a symptom was considered present if the individual, occurring } \\
\text { "sometimes" (3) "many times" (4), or "always" (5) or experiencing it as "some" (3), } \\
\text { "Marked" (4) or "OVERWHELMING" (5)." p.2 } \\
\text { Predictors were included in the initial model } \\
\text { Age; gender; Proficiency in English; exposure to arrest } \\
\text { And the abuse, the traumatic loss, and conflict; and adaptation } \\
\text { Difficulties, threat to the family, determination of residence } \\
\text { Difficulties, health, well-being, difficulties, and asylum } \\
\text { Loss of culture and identity. }\end{array}$ \\
\hline $\begin{array}{l}\text { 5. Confounding factors have } \\
\text { been identified? }\end{array}$ & $\begin{array}{l}\text { Yes. There are factors that may be associated with the outcome that were reported in the study. } \\
\text { During the study, the planning, inclusion was restricted by confounding variables, such as the time. } \\
\text { (Refugges were evaluated in an average of } 4.3 \text { years since the entry of Australia). }\end{array}$ \\
\hline
\end{tabular}




\begin{tabular}{|c|c|}
\hline $\begin{array}{l}\text { 6. Were strategies to deal with } \\
\text { confounding factors stated? }\end{array}$ & $\begin{array}{l}\text { Adjust yes: "Although no census information was available, community leaders identified a potential test } \\
\text { A sample of } 367 \text { individuals based on existing community".p.2 } \\
\text { (..)The fifth class fee was not clearly distinguishable from other classes. Thus, the most parsimonious } \\
\text { Four-class solution was maintained."p.4 }\end{array}$ \\
\hline $\begin{array}{l}\text { 7. The results were measured in } \\
\text { a valid and reliable? }\end{array}$ & $\begin{array}{l}\text { Yes. The measurement tools selected were reliable instruments, such as the Harvard Trauma Questionnaire, the } \\
\text { inventory of complicated grief, the subscale of Checklist-Depression Symptom Hopkins, DSM-IV-derived } \\
\text { algorithm, etc. The author selected that already existed instruments that measure a construction similar to she } \\
\text { wished to measure. } \\
\text { I can identify congruence between the constructions, the instruments and the constructs for this study. } \\
\text { Establishes the author as the measurement was made: "These research assistants received two days of training in } \\
\text { the administration of measures of mental health, and received weekly supervision of the first author"p.3 } \\
\text { Despite this, there is no information on the investigation of three visits in terms of experience in } \\
\text { research. Specificities involved in data collection may have an impact on the results. In addition, participants } \\
\text { literacy levels can affect the quality of the responses, considering the degree of complexity of some of the issues } \\
\text { and the full time needed to the instruments. }\end{array}$ \\
\hline $\begin{array}{l}\text { 8. The statistical analysis used } \\
\text { was adequate? }\end{array}$ & $\begin{array}{l}\text { Yes. } \\
\text { The latent class analysis was important considering that allowed the researcher to find subgroups based on two } \\
\text { main groups originals. "We identified } \\
\text { Latent classes on the basis of dichotomous indicators of PTSD and PGD symptoms. "p. } 3\end{array}$ \\
\hline
\end{tabular}




\begin{tabular}{|l|l|} 
The decision & $\begin{array}{l}\text { According to the critical assessment carried out in accordance with the evaluation criteria for a qualitative study } \\
\text { proposed by the JBI, considers that the article can be included in the study, because it presents } 8 \text { positive } \\
\text { responses. }\end{array}$
\end{tabular}

Adapted from: The Joanna Briggs Institute. (2011). Joanna Briggs Institute Reviewers' Manual. University of Adelaide. Retrieved May 4, 20017, from http://joannabriggs.org/assets/docs/sumari/ReviewersManual-2o11.pdf 